Nevada

Environmental

Restoration

Project

Streamlined Approach for

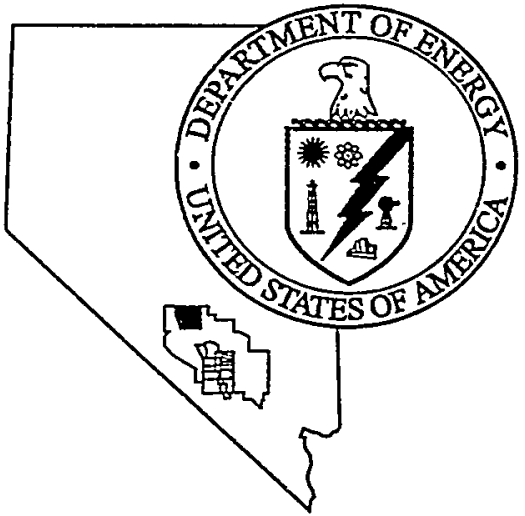

Environmental Restoration Work Plan

For Corrective Action Unit 461:

Joint Test Assembly Sites

And

Corrective Action Unit 495:

Unconfirmed Joint Test Assembly Sites

Tonopah Test Range, Nevada

RECEIV年D

UNCOUTHOB:

JUL 06 OP

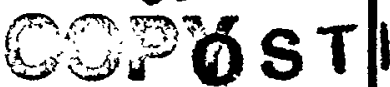

Controlled Copy No.

Revision: 0

August 1998

Approved for public release; further distribution is authorized.

Environmental Restoration

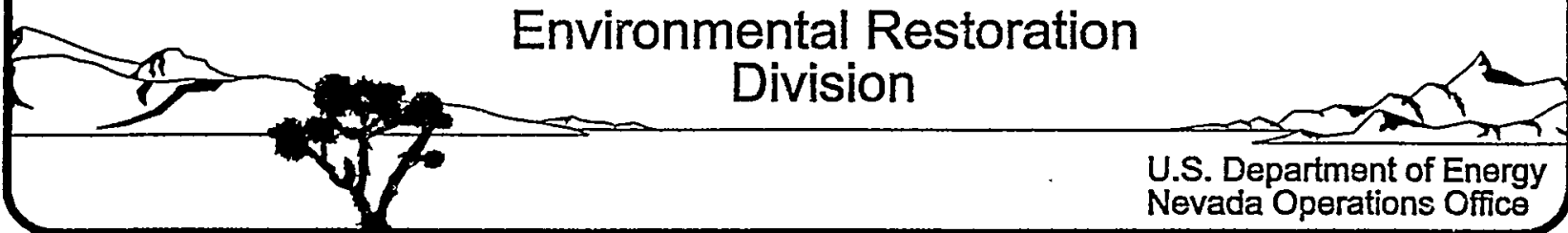


This report has been reproduced from the best available copy.

DOE and DOE contractors can obtain copies of this report from the Office of Scientific and Technical Information, P.O. Box 62, Oak Ridge, TN 37831, (423) 576-8401.

This report is publicly available from the National Technical Information Service, U. S.

Department of Commerce, 5285 Port Royal Road, Springfield, VA, 22161, (703) 487-4650. 


\section{DISCLAIMER}

This report was prepared as an account of work sponsored by an agency of the United States Government. Neither the United States Government nor any agency thereof, nor any of their employees, make any warranty, express or implied, or assumes any legal liability or responsibility for the accuracy, completeness, or usefulness of any information, apparatus, product, or process disclosed, or represents that its use would not infringe privately owned rights. Reference herein to any specific commercial product, process, or service by trade name, trademark, manufacturer, or otherwise does not necessarily constitute or imply its endorsement, recommendation, or favoring by the United States Government or any agency thereof. The views and opinions of authors expressed herein do not necessarily state or reflect those of the United States Government or any agency thereof. 


\section{DISCLAIMER}

Portions of this document may be illegible in electronic image products. Images are produced from the best available original document. 


\title{
STREAMLINED APPROACH FOR ENVIRONMENTAL RESTORATION WORK PLAN FOR \\ CORRECTIVE ACTION UNIT 461: JOINT TEST ASSEMBLY SITES \\ AND \\ CORRECTIVE ACTION UNIT 495: \\ UNCONFIRMED JOINT TEST ASSEMBLY SITES \\ TONOPAH TEST RANGE, NEVADA
}

\author{
Prepared for: \\ U. S. Department of Energy \\ Nevada Operations Office \\ Under Contract No. DE-AC08-96NV11718

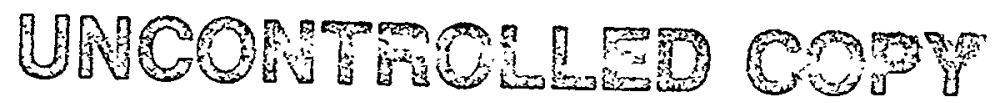 \\ Controlled Copy No.: \\ Revision: 0
}

Prepared by:

Bechtel Nevada

Environmental Restoration

August 1998 


\section{STREAMLINED APPROACH FOR ENVIRONMENTAL RESTORATION WORK PLAN FOR CORRECTIVE ACTION UNIT 461: JOINT TEST ASSEMBLY SITES \\ AND \\ CORRECTIVE ACTION UNIT 495: \\ UNCONFIRMED JOINT TEST ASSEMBLY SITES \\ TONOPAH TEST RANGE, NEVADA}

Approved by: $\frac{5 \text { Janet L. Appenzeller-Wing, Project Mathager }}{\text { Industrial Sites Subproject }}$

Date: $8 / 26 / 98$

Approved by

Date: $8 / 26 / 28$

Nevada Environmental Restoration Project 


\section{EXECUTIVE SUMMARY}

This plan addresses characterization and clean closure of Corrective Action Unit (CAU) 461 and CAU 495 identified in Appendix $\mathrm{II}$ of the Federal Facility Agreement and Consent Order. Both CAUs are located at the Tonopah Test Range (TTR) in south central Nevada. CAUs 461 and 495 consist of the following Corrective Action Sites (CASs):

\section{CAU 461 - Joint Test Assembly (JTA) Sites}

- $\quad$ CAS Number (No.) TTR-001 (1987 W̄79 JTA) - Two locations were identified where a potentially unexploded W79 JTA 20-centimeter (cm) (8-inch [in]) diameter test artillery projectile containing high explosives and depleted uranium (DU) cóuld be buried.

- CAS No. TA-52-003-0960 (DU Artillery Round Number 2) - Two witness bars are located above a detonated, buried W79 20-cm (8-in) diameter DU artillery round.

- CAS No. TA-52-002-TAML (DU Impact Site) - Is an area of disturbed ground containing surface and subsurface metal fragments and DU impacted soil from a failed weảpons test.

\section{CAU 495 - Unconfirmed JTA Sites}

- CAS No. TA-55-007-09SE (Buried Artillery Round No. 3) - Impact site of failed DU artillery round test package.

- CẮS No. TA-55-006-09SE (Buried Artillery Round No. 4) - Impact site of failed DU artillery round test package.

Closure for these sites will be completed by:

- Excavating and evaluating the condition of each artillery round (if found).

- Detonating the rounds (if necessary).

- Excavate the impacted soil and debris.

- Collect verification samples.

- Backfill the excavations. 
- Dispose of the impacted soil and debris at.an approved low-level waste repository at the Nevada Test Site.

CAS No. TA-52-002-TAML will require surficial cleanup and sampling prior to subsurface activities. 


\section{TABLE OF CONTENTS}

ACRONYMS AND ABBREVIATIONS $\ldots \ldots \ldots \ldots \ldots \ldots \ldots \ldots \ldots \ldots \ldots \ldots \ldots$ vi

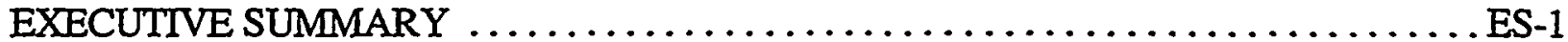

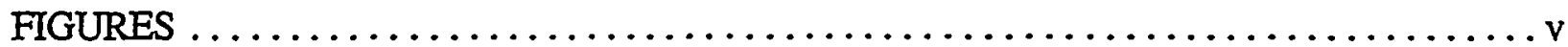

TABLES $\ldots \ldots \ldots \ldots \ldots \ldots \ldots \ldots \ldots \ldots \ldots \ldots \ldots \ldots \ldots \ldots \ldots \ldots \ldots \ldots \ldots$

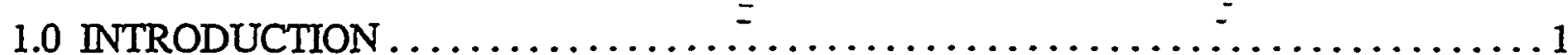

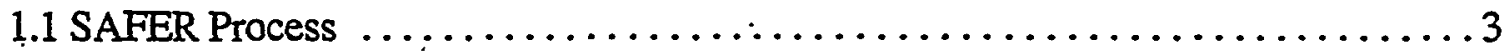

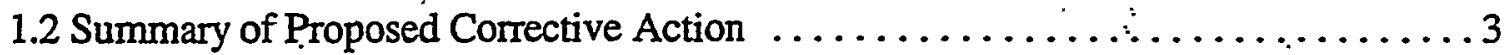

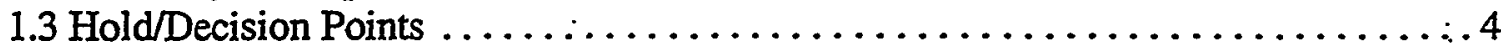

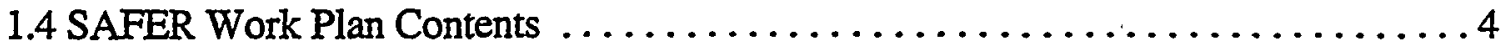

2.0 UNIT DESCRIPTION AND CLOSURE OBJECTIVES $\ldots \ldots \ldots \ldots \ldots \ldots \ldots \ldots \ldots$

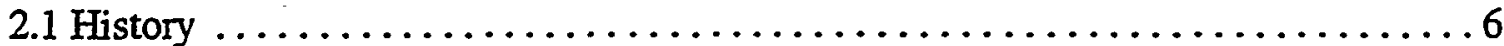

2.1.1 CAS No. TTR-001: 1987 W-79 JTA . ................... 6

2.1.2 CAS No. TA-52-003-0960: DU Artillery Round No. $2 \ldots \ldots \ldots \ldots \ldots 6$

2.1.3 CAS No. TA-52-002-TAML: Depleted Uranium Impact Site . . . . . . . 8

2.1.4 CAS No. TA-55-007-09SE: Buried Artillery Round No. 3 . . . . . . . . 8

2.1.5 CAS No. TA-55-006-09SE: Buried Artillery Round No. 4 . . . . . . . 8

2.2 Site Location and Description .......................... 9

2.2.1 CAS No. TTR-001: 1987 Wं-79 JTA ................... . 9

2.2.2 CAS No. TA-52-003-0960: DU Artillery Round No. 2 . . . . . . . . . . . 9

2.2.3 CAS No. TA-52-002-TAML: Depleted Uranium Impact Site . . . . . . . . 9

2.2.4 CAS No. TA-55-007-09SE: Buried Artillery Round No. 3 . . . . . . . . 9

2.2.5 CAS No. TA-55-006-09SE: Buried Artillery Round No. 4 . . . . . . . 14

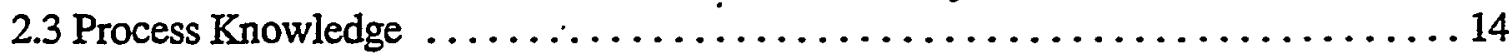

2.3.1 CAS No. TTR-001: 1987 W-79 JTA . . . . . . . . . . . . . 14

2.3.2 CAS No. TA-52-003-0960: DU Artillery Round No. 2 . . . . . . . . . . . 14

2.3.3.CAS No. TA-52-002-TAML: Depleted Uranium Impact Site . . . . . . . . 16

2.3.4 CAS No. TA-55-007-09SE: Buried Artillery Round No. 3 : . . . . . . . 16

2.3.5 CAS No. TA-55-006-09SE: Buried Artillery Round No. 4 . . . . . . . 17

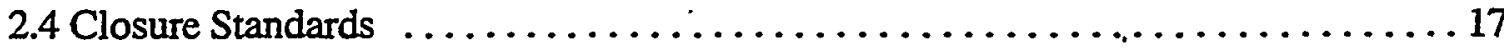

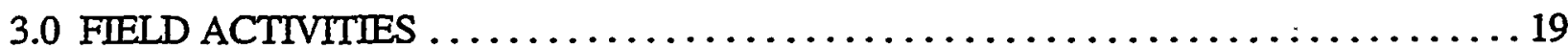

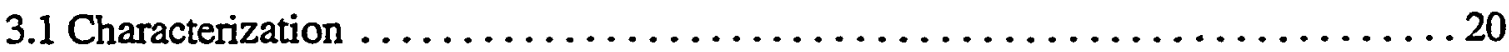

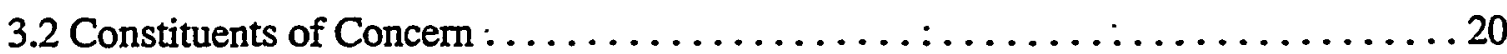

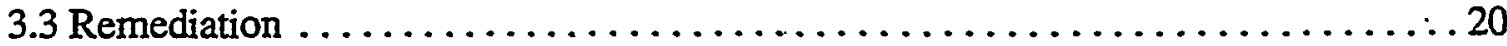

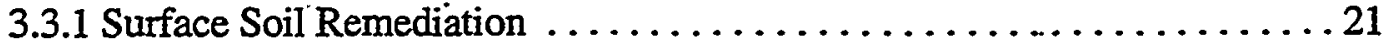

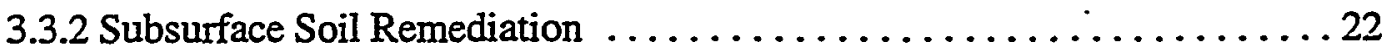




\section{TABLE OF CONTENTS (continued)}

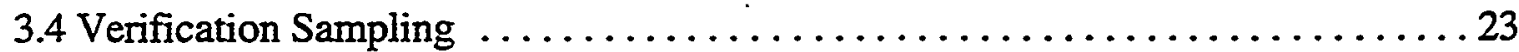

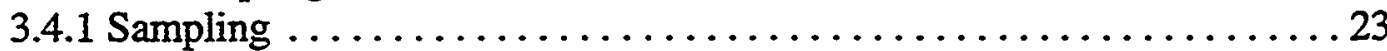

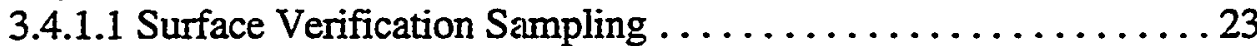

3.4.1.2 Subsurface Verification Sampling $\ldots \ldots \ldots \ldots \ldots \ldots \ldots .26$

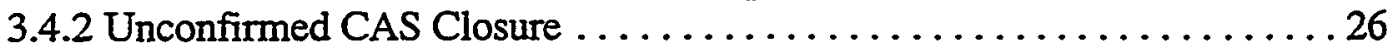

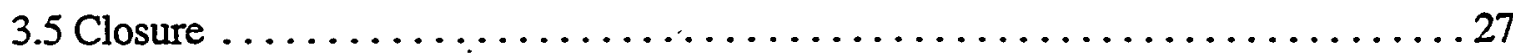

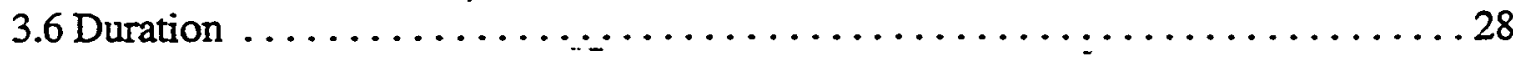

4.0 REPORTS AND RECORDS AVAILABIITY $\ldots \ldots \ldots \ldots \ldots \ldots \ldots \ldots \ldots \ldots \ldots \ldots$

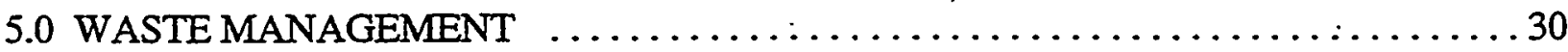

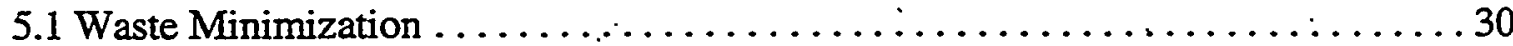

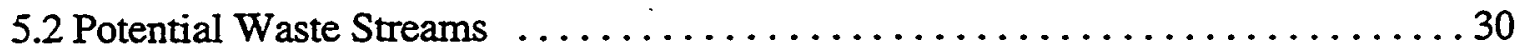

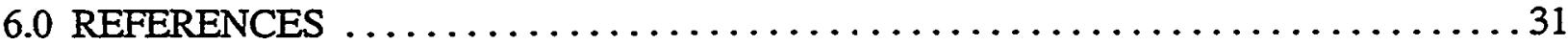

APPENDIX A - PROJECT ORGANIZATION

APPENDIX B - NEVADA DIVISION OF ENVIRONMENTAL PROTECTION DOCUMENT REVIEW SHEET

DISTRIBUTION LIST 


\section{TABLE OF CONTENTS (continued)}

\section{FIGURES}

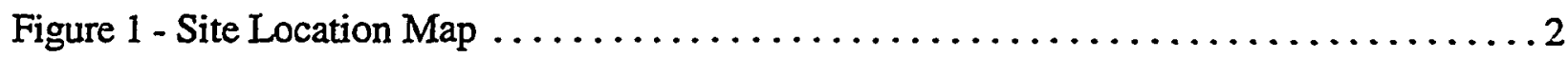

Figure 2 - Approximate Location of Depleted Uranium Artillery Rounds Nos. 1 through 4 and the Depleted Uranium Impact Site

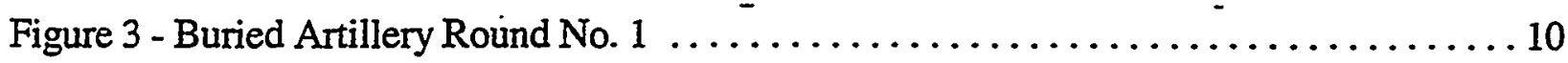

Figure 4 - Buried Artillery Round No. $2 \ldots \ldots \ldots \ldots \ldots \ldots \ldots \ldots \ldots \ldots \ldots \ldots \ldots \ldots \ldots \ldots \ldots$

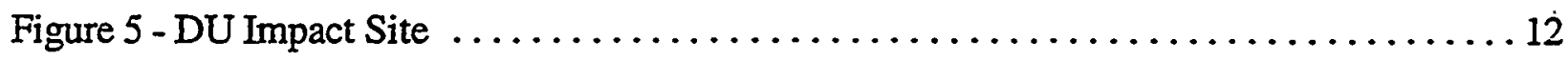

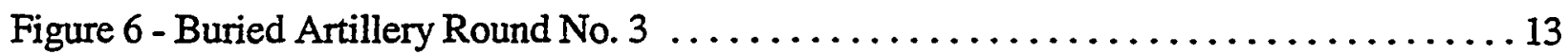

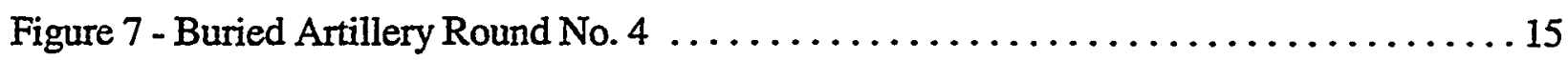

\section{TABLES}

Table 1 - Suspected Constituents of Concern and Closure Standards $\ldots \ldots \ldots \ldots \ldots \ldots$

Table 2 - Closure Verification Analytical Requirements ...................... 24 


\section{ACRONYMS AND ABBREVIATIONS}

\begin{tabular}{|c|c|}
\hline CAS & Corrective Action Site \\
\hline $\mathrm{CAU}$ & Corrective Action Unit \\
\hline $\mathrm{cm}$ & centimeter \\
\hline $\mathrm{COC}$ & Constituents of Concern :- \\
\hline DOE & U.S. Department of Energy \\
\hline DOE/NV & U.S. Department of Energy, Nevada Operations Office \\
\hline DOT & U.S. Department of Transportation \\
\hline DQO & Data Quality Objective \\
\hline DU & Depleted Uranium \\
\hline $\mathrm{EOD}$ & Explosive Ordnance Disposal \\
\hline FFACO & Federal Facility Agreement and Consent Order \\
\hline $\mathrm{ft}$ & feet \\
\hline $\mathrm{G}$ & gallon \\
\hline HASP & Health and Safety Plan \\
\hline $\mathrm{HE}$ & High Explosive \\
\hline in & inch \\
\hline JTA & Joint Test Assembly \\
\hline $\mathrm{kg}$ & kilogram \\
\hline & kilometer \\
\hline
\end{tabular}




\section{ACRONYMS AND ABBREVIATIONS (continued)}

$\mathrm{lb}$

pound

LLW

low-level waste

L liter

m

meter

$\mathrm{m}^{3}$

cubic meter

NDEP Nevada Division of Environmental Protection

NEPA National Environmental Policy Act

No. Number

NTS Nevada Test Site

PPE Personal-Protective Equipment .

RCRA. Resource Conservation and Recovery Act

RCT Radiological Control Technician

RWAP Radioactive Waste Acceptance Program

RWP Radiological Work Permit

SAFER : Streamlined Approach for Environmental Restoration

SAIC Science Applications International Corporation

SNL Sandia National Laboratories

SVOC . Semi-volatile Organic Compound

TCLP Toxicity Characteristic Leaching Procedure

TTR Tonopah Test Range

$\mathrm{yd}^{3} \quad$ cubic yard

vii . 


\subsection{INTRODUCTION}

This Streamlined Approach for Environmental Restoration (SAFER) plan addresses the action necessary for the clean closure of Corrective Action Unit (CAU) 461 (Test Area Joint Test Assembly (JTA) Sites) and CAU 495 (Unconfirmed JTA Sites). The CAU's are currently listed in Appendix III of the Federal Facility Agreement and Consent Order (FFACO). Both CAUs are located at the Tonopah Test Range (TTR) in south central Nevada (Figure 1). CAUs 461 and 495 consist of the following Corrective Action Sites (CASs):

\section{CAU 461 - Joint Test Assembly (JTA) Sites}

- CAS Number (No.) TTR-001 (1987 W79 JTA) - A potentially unexṕloded W79 JTA 20centimeter $(\mathrm{cm})$ (8-inch [in]) diameter test artillery projectile containing high explosives (HE). and depleted uranium (DU). Two areas are identified as possible locations for this CAS.

- CAS No. TA-52-003-0960 (DU Artillery Round Number 2) - A detonated, buried W79 $20-\mathrm{cm}(8-\mathrm{in})$ diameter DU artillery round which is located under two witness bars.

- $\quad$ CAS No. TA-52-002-TAML (DU Impact Site) - Is an area 55 meters (m) by 50 meters (m) (180 feet [ft] by 160 feet [ft]) of disturbed ground containing metal fragments and DU impacted soil from a failed weapons test. Historical documentation and fragment examination suggest that during the $1960 \mathrm{~s}$, a $150-\mathrm{cm}$ (60-in) diameter weapons test unit incurred parachute failure, impacted, and released DU.

\section{CAU 495 - Unconfirmed JTA Sites}

- CAS No. TA-55-007-09SE (Buried Artillery Round No. 3) - This site is believed to be the impact site of a failed DU artillery round test package. No reliable information exists . as to the date of the test or the existence of the round. However, a geophysical survey conducted in early 1998 concluded that it is plausible the round is present (Science Applications International Corporation [SAIC], 1998).

CAS No. TA-55-006-09SE (Buried Artillery Round No. 4) - This CAS is believed to be the impact site of a failed DU artillery round test package. Reliable information does not exist as to the date of the test or the existence of the round. However, data from a geophysical survey in early 1998 may have identified the artillery round (SAIC, 1998). 


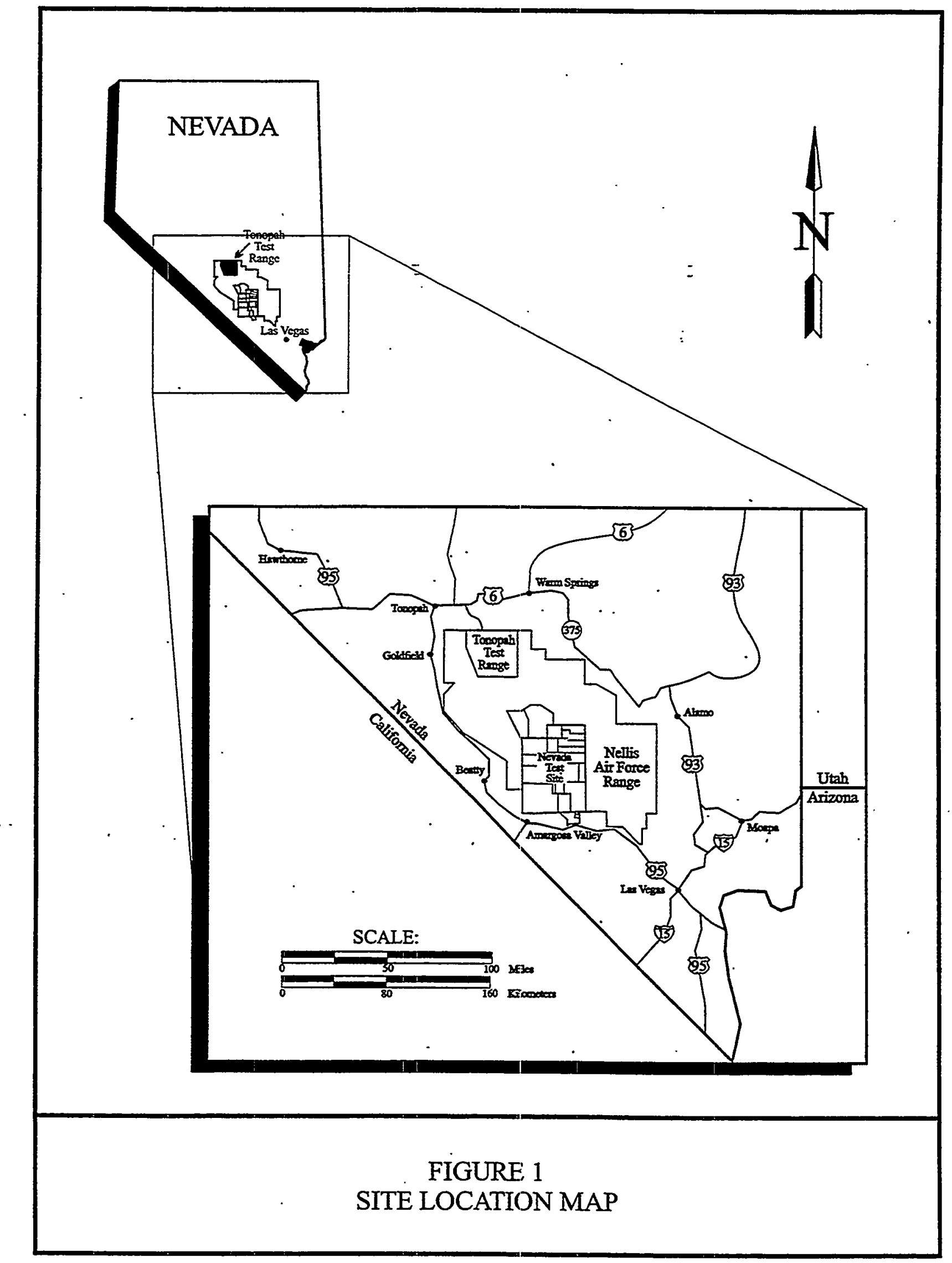


This plan provides the methodology for clean closure of the CASs. The sites contain DU and the explosive compound hexahydro-1,3,5-trinitro-1,3,5-triazine. Projectile component metals such as beryllium, chromium, mercury; and lead may also be present. Radiological surveys conducted in January and March 1998 indicate that only CAS No. TA-52-002-TAML contains detectable amounts of surface radiation (IT, 1998c). Based upon preassessment field work, there is sufficient process knowledge of site activities to clean close CAU 461 and CAU 495 using the SAFER process.

\subsection{SAFER PROCESS}

The SAFER process combines elements of the Data Quality Objectives (DQO) process and the observational approach to help plan and conduct corrective actions. DQOs are used to identify the problem and define the type and quality of data needed to complete the investigation phase of the process. The observational approach provides a framework for managing uncertainty and planning decision making. The purpose of the investigation in the SAFER process is to verify the adequacy of existing information to implement the corrective action.

Use of the SAFER concept allows for technical decisions to be made based on incomplete, but sufficient information, and the experience of the decision maker. Any uncertainties are addressed by documented assumptions that are verified by sampling and analyses, data evaluation, and on-site observations as planned activities progress, and by contingency plans as necessary. The remediation and closure may proceed simultaneously with site characterization as sufficient data are gathered to confirm or disprove the assumptions made in selecting the closure method. If, at any time during the site closure, new information is developed that indicates that the closure method should be revised, the closure activities will be redirected to more appropriately protect human health and the environment.

Closure of CAU 461 and CAU 495 will consist primarily of excavation and removal activities. In addition, sufficient process knowledge and knowledge of the Constituents of Concern (COC) exist such that closure can be completed using the SAFER process.

\subsection{SUMMARY OF PROPOSED CORRECTIVE ACTION}

Closure for CAU 461 will be completed by the following:

- CAS No. TTR:001 - Excavation, possible detonation, and removal of the artillery shell and impacted soil.

- CAS No. TTR-52-003-0960 - Excavation and removal of debris and impacted soil.

- CAS No. TA-52-002-TAML - Cleanup and removal of surface debris and soil and excavation and removal of subsurface debris and soil. 
- Closure of both CASs in CAU 495 will be completed by: excavation, possible detonation, and removal of the artillery round and impacted soil.

\subsection{HOLD/DECISION POINTS}

During characterization and closure activities, certain conditions affecting the project schedule and budget may require decisions to be made prior to continuing work. Work stoppage conditions may include:

- Finding only "warmer rounds" (inert, concrete-filled rounds containing no HE fired prior to official tests to warm the guns and test the trajectory instrumentation) where DU rounds were anticipated.

- Finding no rounds (warmer or DU) after excavating $3 \mathrm{~m}(10 \mathrm{ft})$ and metallic anomalies arẹ no longer detected.

- Generating a greater volume of impacted material than expected.

If any of these conditions occur, work will stop and the Department of Energy (DOE) and the Nevada Division of Environmental Protection (NDE]?) will be notified. Work will continue when a decision has been made.

\subsection{SAFER WORK PLAN CONTENTS}

This SAFER Work Plan has been developed to support the proposed characterization and closure of CAU 461 and CAU 495. The format of the plan is: -

- Introduction (Section 1.0)

- Unit Description and Closure Objectives (Section 2.0)

- $\quad$ Field Activities (Section 3.0)

- Reports and Records Availability (Section 4.0)

- Waste Management (Section 5.0)

- $\quad$ References (Section 6.0) 
This plan was developed using information and guidance provided from the following documents:

- Nevada Environmental Restoration Project, Project Management Plan, Revision 0, DOE, 1994.

- Nevada Environmental Restoration.Project. Industrial Sites, Quality Assurance Project Plan, Nevada Test Site, Revision 1, DOE, 1996, DOE/NV-372.

- Draft Streamlined Approach for Environmental Restoration Plain for Corrective Action Unit 430, Buried Depleted Uranium Artillery Round No. 1. Tonoaph Test Range, DOE, May, 1996.

First Quarter 1998 Surface Geophysical Survey Report. Depleted Uranium Impact Site (CAU 461), 1987 W79 Joint Test Assembly (CAU 461) Sites A and B, and Buried Artillery Rounds (CAU -495) \#3 and \#4, Tonopah Test Range, Nevada, SAIC, May 1998.

In addition, records of interviews, field notes, letters, and memoranda from International Technology Corporation (IT) project files were also used in the development of this plan. 


\subsection{UNIT DESCRIPTION AND CLOSURE OBJECTIVES}

Both CAU 461 and CAU 495 are located on the TTR. Of the five CASs, four (TTR-001, TA-52003-0960, TA-55-007-09SE, and TA-55-006-09SE) are located downrange (south) of the Area 9 Complex south of Avenue 13. The remaining CAS (TA-52-002-TAML) is located approximately $758 \mathrm{~m}(2,500 \mathrm{ft})$ east of the concrete "Hard Target" on the southern edge of Main Lake (Figure 2).

\subsection{HISTORY}

\subsubsection{CAS No. TTR-001: 1987 W-79 JTA}

This CAS was formerly known as CAU 430, Buried DU Artillery Round No. 1. The CAU and CAS number and name were closed when the disturbed ground at this location was found to contain an inert warmer round and not the JTA. The present CAS number was assigned after additional information on potential DU Artillery Round No. 1 impact areas were discovered in 1997. The site consists of a potentially unexploded W79 JTA $20-\mathrm{cm}$ (8-in) diameter test artillery projectile containing $H E$ and $D U$.

The procedure for testing the projectile normally involved firing the projectile from a $20-\mathrm{cm}$ (8in) artillery gun. The gun was located in Area 9 of the TTR and the projectile was fired southward at an angle of 87 degrees. A parachute was to deploy during the projectile's descent to facilitate recovery of the undamaged projectile. However, the parachute failed to deploy, resulting in a "hard" landing. The resulting damage prevented normal recovery operations.

Available information report that the DU round was exposed by excavating, C-4 explosive was placed in contact with the projectile, and the hole backfilled (DOE, 1996a). The C-4 was detonated, however, radiation was not detected at the surface and only a small amount of ejecta was produced. The detonation of the $\mathrm{C}-4$ was designed to create a sympathetic detonation with the existing HE and destroy the projectile. This was to be inferred by the resultant "burp" (release) of gamma radiation at the ground surface from the DU. Since there was no "burp" of radiation at the surface, a sympathetic detonation may not have occurred. These activities most likely took place in 1986 (IT, 1998a).

\subsubsection{CAS No. TA-52-003-0960: DU Artillery Round No. 2}

This CAS consists of a buried W79 20-cm (8-in) diameter DU artillery round. During test activities, parachute failure of the projectile resulted in a "hard landing" and resulting damage to the projectile. It was determined by range personnel that destruction of the round was necessary for safety and declassification purposes. The round was lowered into a 6-m (20-ft) excavation along with two flat steel "witness bars" and approximately 5.4 kilograms (kg) (12 pounds [lb]) 


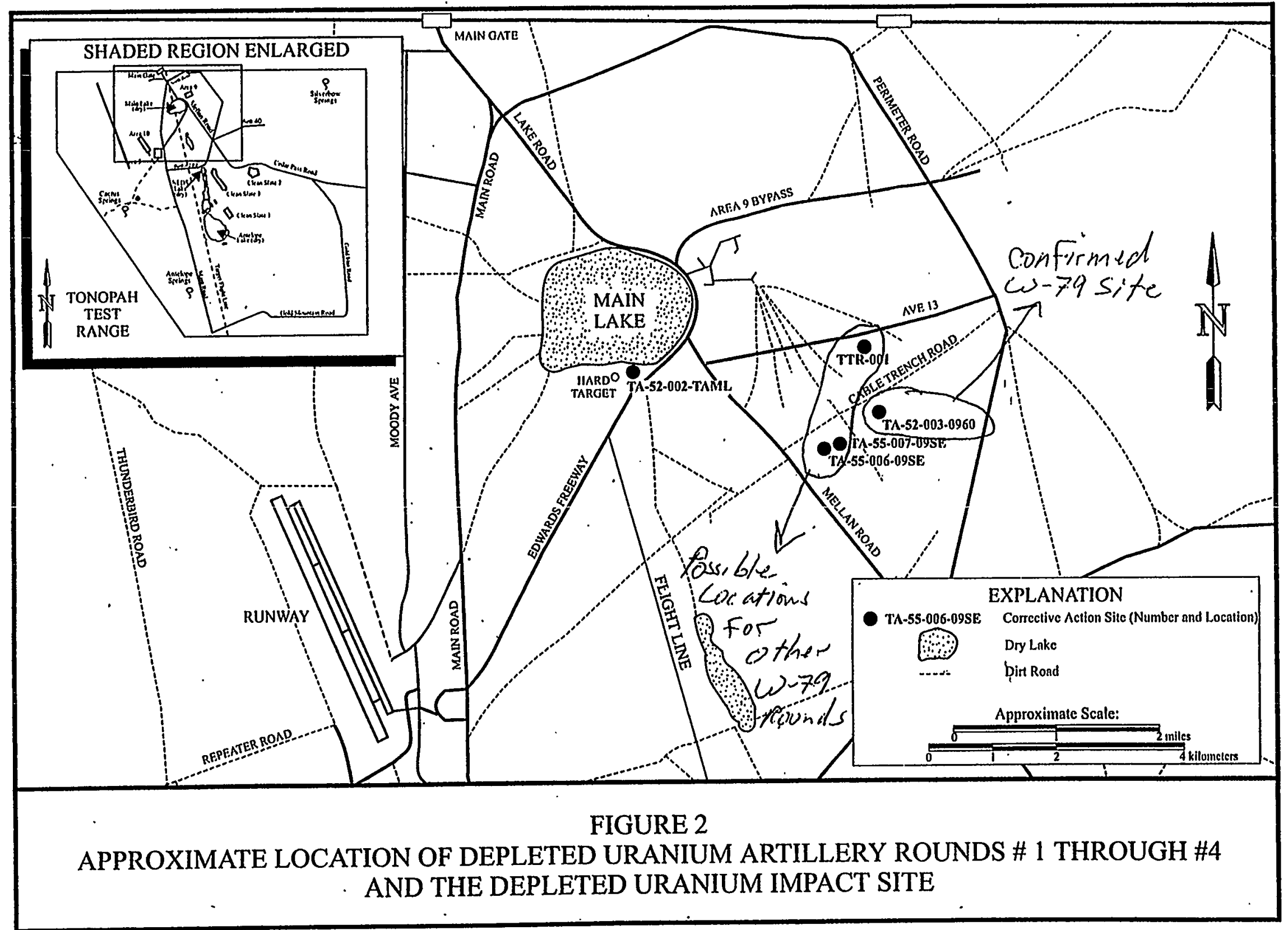


of $\mathrm{C}-4$ explosive. The excavation was then backfilled and the $\mathrm{C}-4$ detonated with detacord. The detacord created a pathway to the surface where DU was able to "burp" up and contaminate the surface. This burp indicates that the HE within the artillery round detonated sympathetically with the C-4. Range personnel also conducted a cleanup of the small particles of DU on the surface. Records indicate that the detonation occurred in 1989 (DOE, 1994a; IT, 1998b; Sandia, 1990).

\subsubsection{CAS No. TA-52-002-TAML: Depleted Uranium Impact Site =}

This CAS consists of an area of disturbed ground containing metal fragments and DU from a failed weapons test. Historical documentation and fragment examination suggest that during the $1960 \mathrm{~s}$, a 1.5-m (60-in) diameter weapons test unit incurred parachute failure, impacted, and released DU. .

The site was discovered in July 1991 during routine cleanup of an old impact site. Range personnel discovered a significant quantity of yellow metal believed to be DU. Subsequent actions resulted in the excavation of approximately eight 208-liter (L) (55-gallon [G]) drums of metal fragments and contaminated soil. Cleanup was stopped after it was determined that the waste was more extensive than anticipated and the excavated area was covered with clean fill. The area was isolated with a 55 by $50-\mathrm{m}$ (180 by $160-\mathrm{ft})$ fence and.posted as a Radiological Control Area (IT, 1998c).

Samples were collected in 1991 and 1996 and analyzed for radiological isotopes and Resource Conservation and Recovery Act (RCRA) metals. The results of these analyses indicate the presence of DU and the metals barium, chromium, and lead above regulatory levels (Rarrick, 1991; Sandia, 1997).

\subsubsection{CAS No. TA-55-007-09SE: Buried Ártillery Round No. 3}

This CA $\dot{S}$ is believed to be the impact site of a failed DU artillery round test package. No reliable information exists as to the date of the test or the existence of the round. However, a geophysical survey conducted in early 1998 concluded that it is plausible the round is present (SAIC, 1998).

\subsubsection{CAS No. TA-55-006-09SE: Buried Artillery Round No. 4}

This CAS is believed to be the impact site of a failed DU artillery round test package. Reliable information does not exist as to the date of the test or the existence of the round. However, data - from a geophysical survey in early 1998 may have identified the artillery round (SAIC, 1998). 


\subsection{SITE LOCATION AND DESCRIPTION}

\subsubsection{CAS No. TTR-001: 1987 W-79 JTA}

The CAS consists of two potential burial sites: Site A and Site B. Both sites are located south of Area 9 off Avenue 13 (Figure 3). Site A consists of two 1-m (3-ft) diameter circular mounds. The Nevada State Plane coordinates for Site A are N 1,120,033 ft and E 493,590.4 ft. Site B consists of a $3-\mathrm{m}(10-\mathrm{ft})$ by $2.4-\mathrm{m}(8-\mathrm{ft})$ rectangular depression. The Nevada State Plane coordinates for Site B are N 1,120,108 ft-and E 493,423.7 ft (IT, 1998).

The work to be done at this CAS includes the excavation, possible detonation, and removal of the artillery round and impacted soil.

\subsubsection{CAS No. TA-52-003-0960: DU Artillery Round No. 2}

This CAS is located approximately $4.0 \mathrm{~km}$ ( 2.5 miles) southeast of Area 9 off Avenue 13 . It consists of a 7.6-m (25-ft) by $4.5-\mathrm{m}(15-\mathrm{ft})$ by $1-\mathrm{m}(3-\mathrm{ft})$ mound of soil and can be identified by two steel "witness bars" protruding from the top of the mound (Figure 4). The Nevada State Plane coordinates for this site are N 1,119, $622 \mathrm{ft}$ and $\mathrm{E} 497,976.8 \mathrm{ft}$ (Rodriguez, 1997).

Work to be conducted at this CAS includes excavation and removal of debris and impacted soil.

\subsubsection{CAS No. TA-52-002-TAML: Depleted Uranium Impact Site}

This CAS is located on the southeast margin of Main Lake just north of Edwards Freeway. It consists of a disturbed area surrounded by a 55 by $50-\mathrm{m}$ (180 by $160-\mathrm{ft}$ ) fence (Figure 5$)$. The Nevada State Plane coordinates for this site are N 1,122,721 ft and E 484,274.5 ft (Rodriguez, 1997). .

Work to be done at this CAS includes cleanup and removal of surface debris and soil and excavation and removal of subsurface debris and soil.

\subsubsection{CAS No. TA-55-007-09SE: Buried Artillery Round No. 3}

This CAS is located south of Area 9 off Avenue 13. It consists of a $1.5-\mathrm{m}$ (5-ft) by $2.4-\mathrm{m}(8-\mathrm{ft})$ by $1-\mathrm{m}$ (3-ft) deep depression (Figure 6 ). The Nevacla State Plane coordinates for this site are $\mathrm{N}$ $1,116,808 \mathrm{ft}$ and $\mathrm{E} 493,332.3 \mathrm{ft}$.

Work to be done at this CAS includes excavation, possible detonation, and removal of the artillery round and impacted soil. 


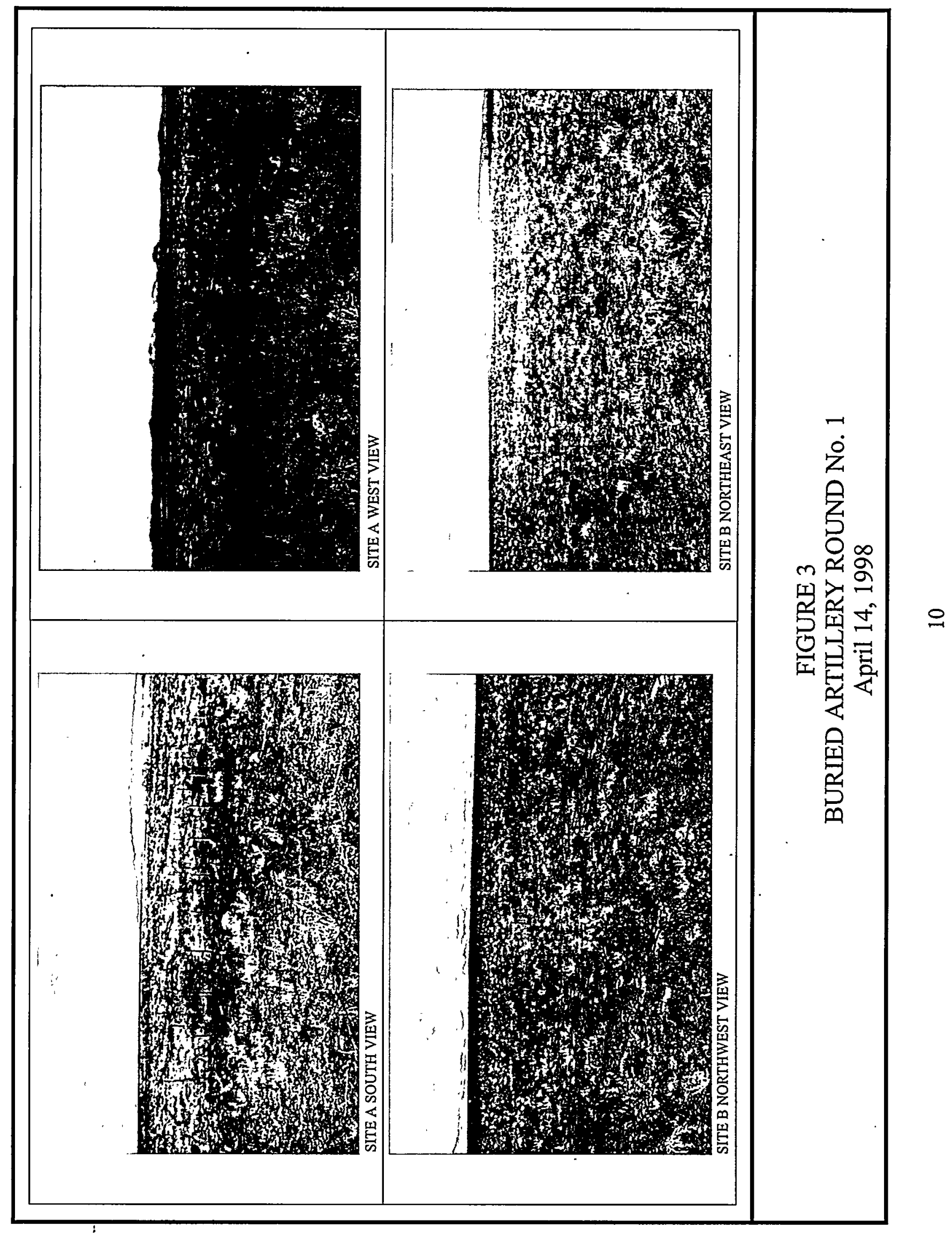




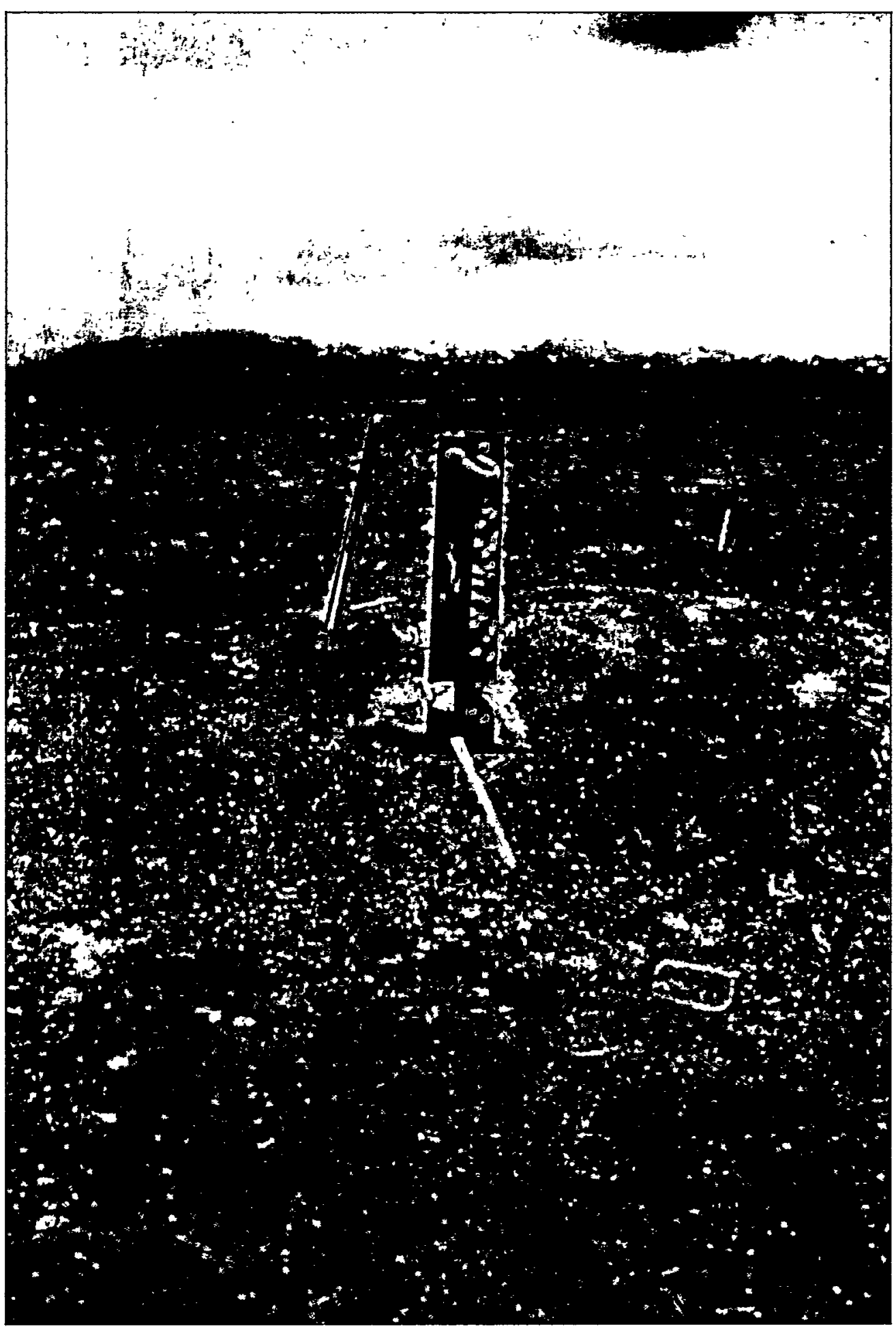

FIGURE 4

BURIED ARTILLERY ROUND No. 2

April 14, 1998 


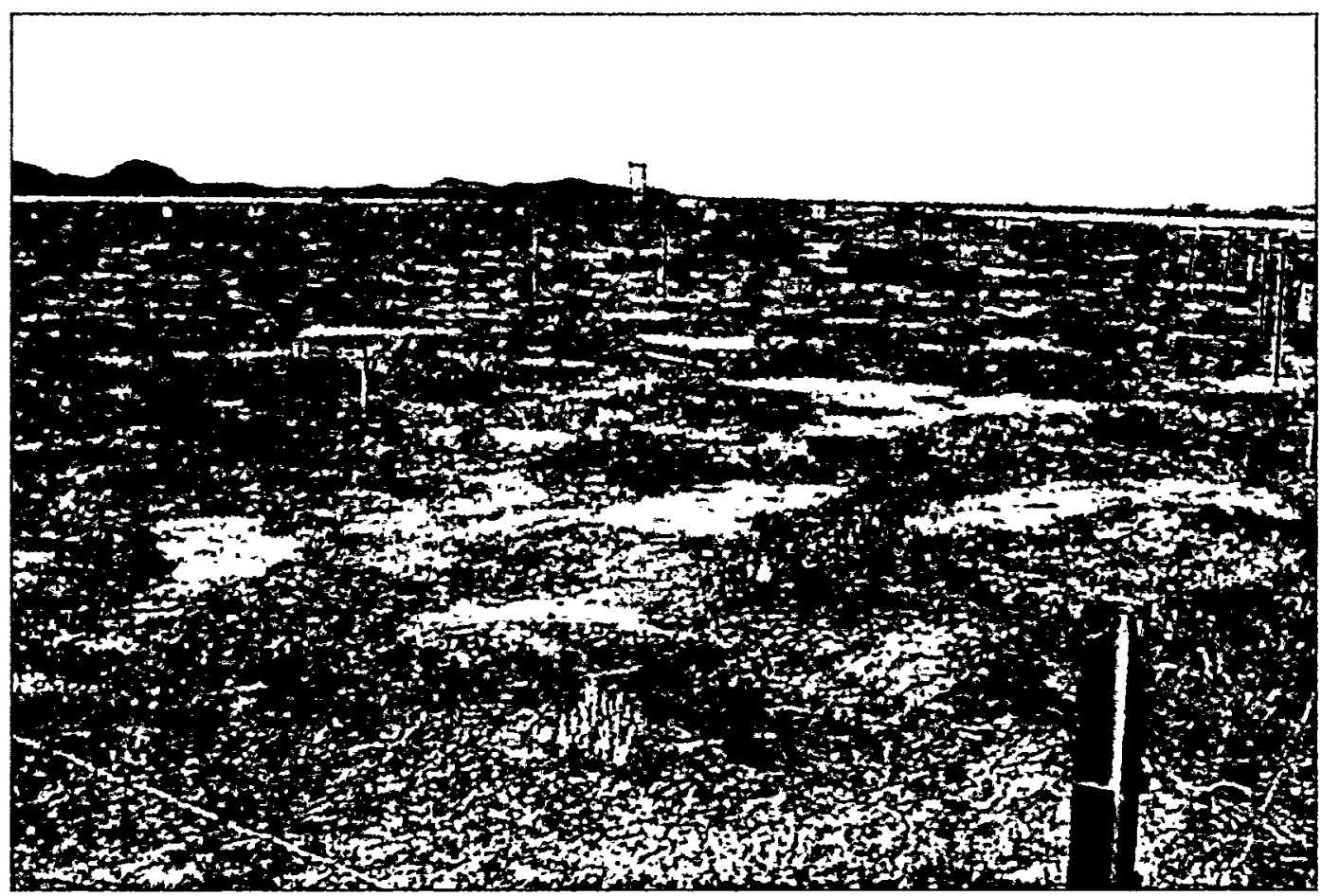
NORTHWEST VIEW

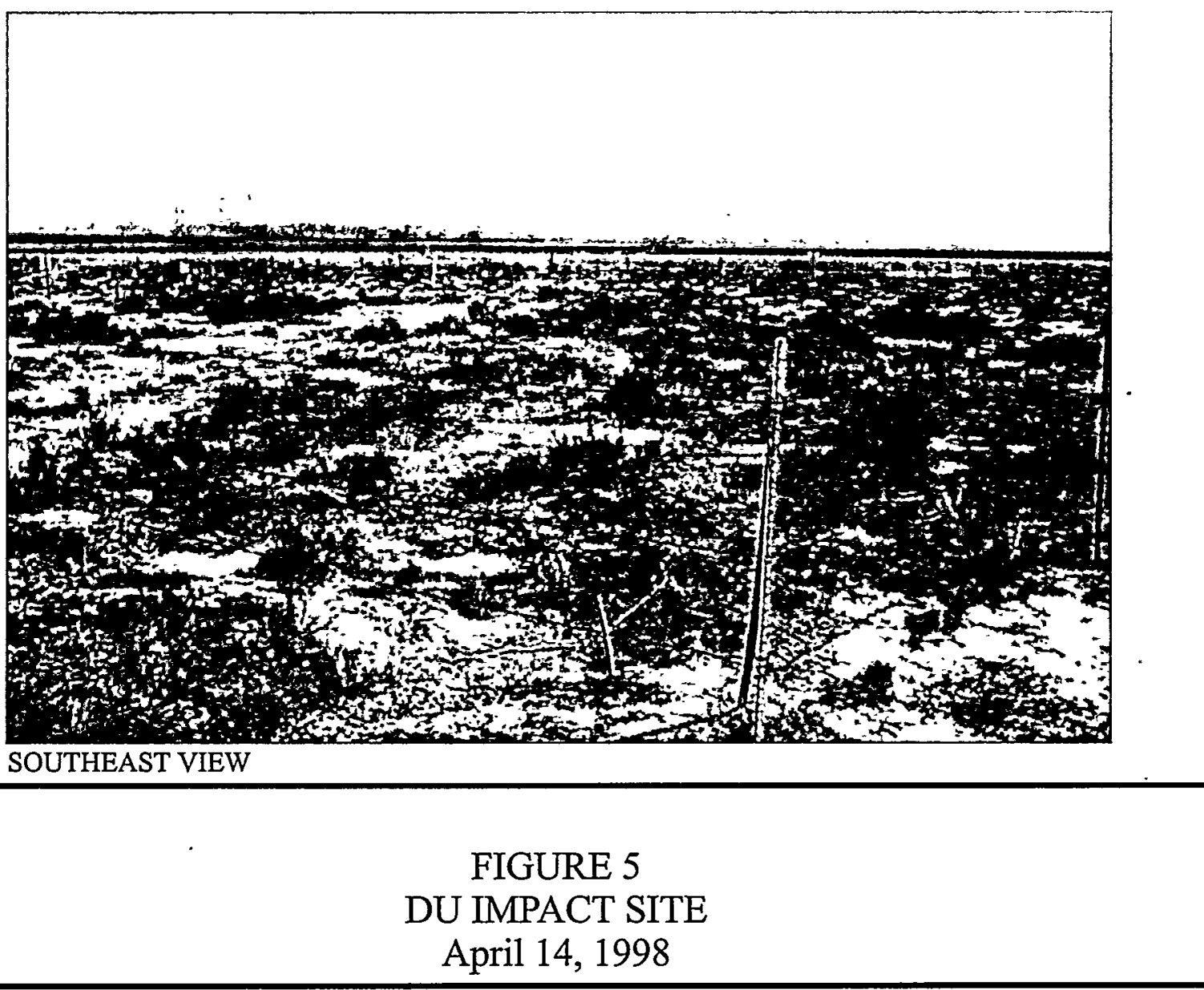




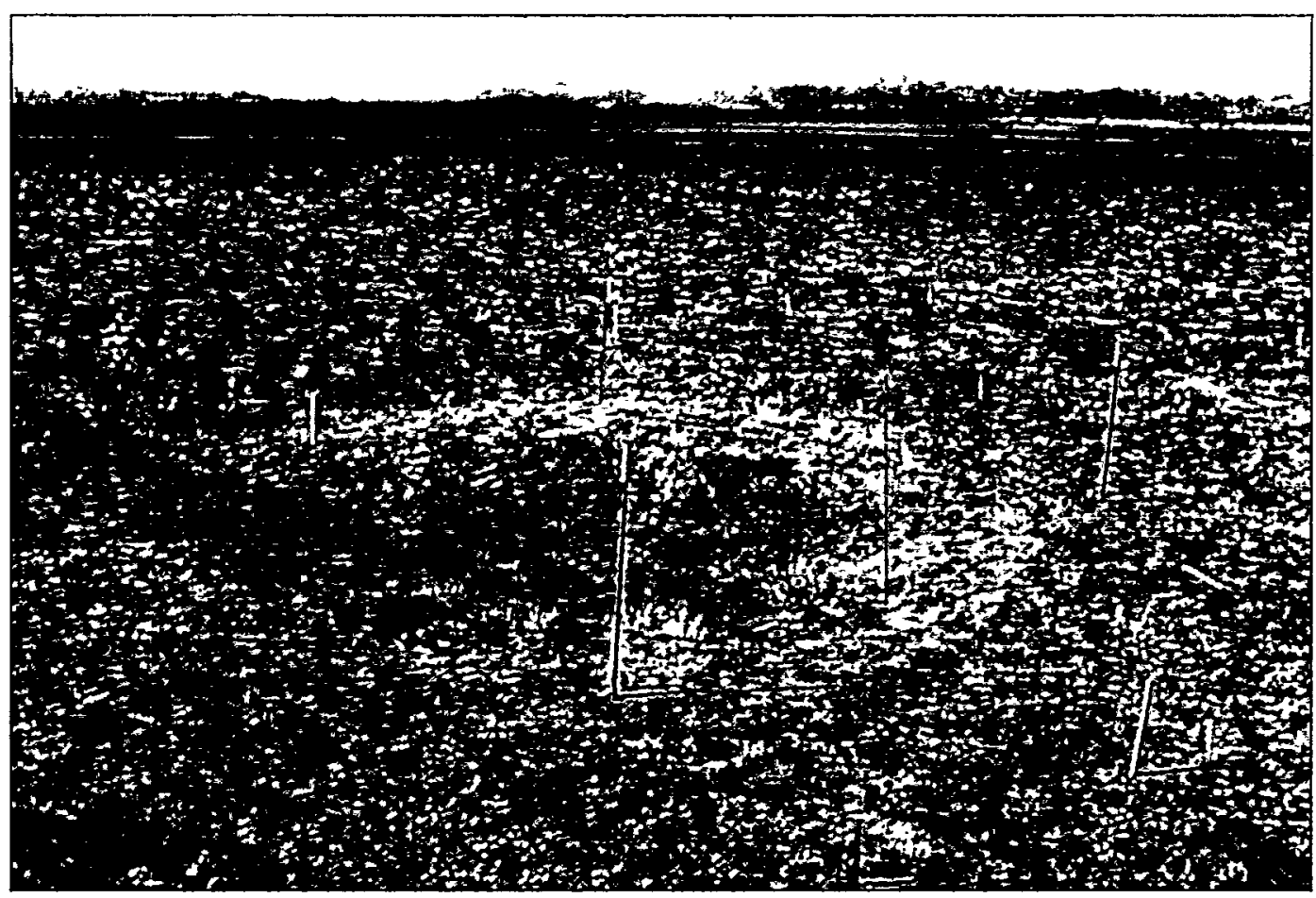

WEST VIEW

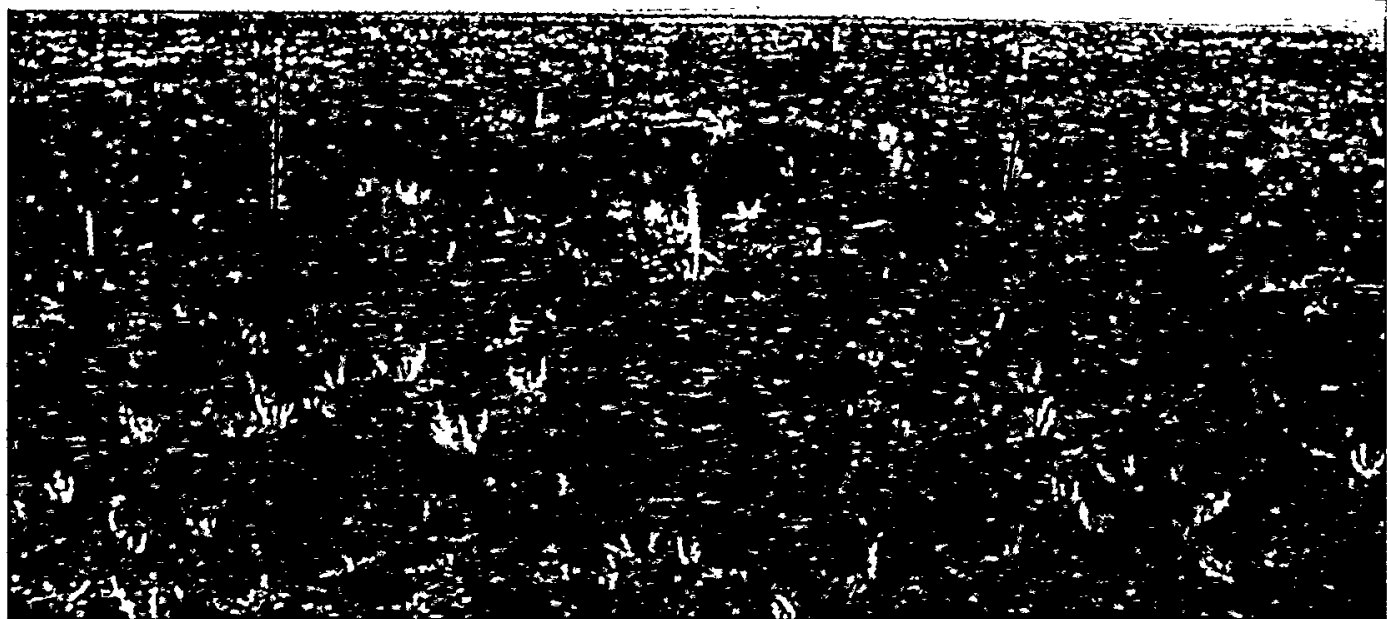

SOUTH VIEW

FIGURE 6

BURIED ARTILLERY ROUND No. 3

April 14, 1998 


\subsubsection{CAS No. TA-55-006-09SE: Buried Artillery Round No. 4}

This CAS is located south of Area 9 off Avenue 13. It consists of a $1.5-\mathrm{m}(5-\mathrm{ft})$ by $2.4-\mathrm{m}(8-\mathrm{ft})$ by 1-m (3-ft) deep depression (Figure 7). The Nevada State Plane coordinates for this site are $\mathrm{N}$ $1,116,935.5 \mathrm{ft}$ and $\mathrm{E} 493,548.9 \mathrm{ft}$.

Work to be performed at this CAS includes excavation, possible detonation, and removal of the artillery round and impacted soil.

\subsection{PROCESS KNOWLEDGE}

Process knowledge is based on interviews of personnel involved with the project and a review of historical records, geophysical surveys, and logs of field activities during the original test and associated activities. This information was obtained during preliminary assessment of the CAUs (IT Project Files) and during a geophysical survey (SAIC, 1998). . For all the CASs, the only COCs are DU, HE residues, and possibly metals from detonated weapon components.

\subsubsection{CAS No. TTR-001: 1987 W-79 JTA}

This site consists of two possible locations for the projectile: Site A and Site B. An attempt was made to detonate the HE in the round using $\mathrm{C}-4$. It is unknown whether the round detonated, but it is suspected that it did not. This is based on there being no "burp" of radiation to the surface and only a limited amount of ejecta from the detonation.

Geophysical surveys indicate that there are two possible locations for the projectile at Site A. Results of the geophysical survey at Site B indicate a probable location for the projectile at 1-m. (3-ft) below ground surface (SAIC, 1998). A radiological survey in January and March 1998 indicates there is no surficial radiological measurements above background (IT, 1998a).

\subsubsection{CAS No. TA-52-003-0960: DU Artillery Round No. 2}

This site consists of a buried W79 20-cm (8-in) diameter DU artillery round and can be identified by a $7.6-\mathrm{m}(25-\mathrm{ft})$ by $4.5-\mathrm{m}(15-\mathrm{ft})$ by $1-\mathrm{m}$ (3-ft) soil mound and two steel "witness bars" protruding from the top of the mound. The round was detonated in 1989. 


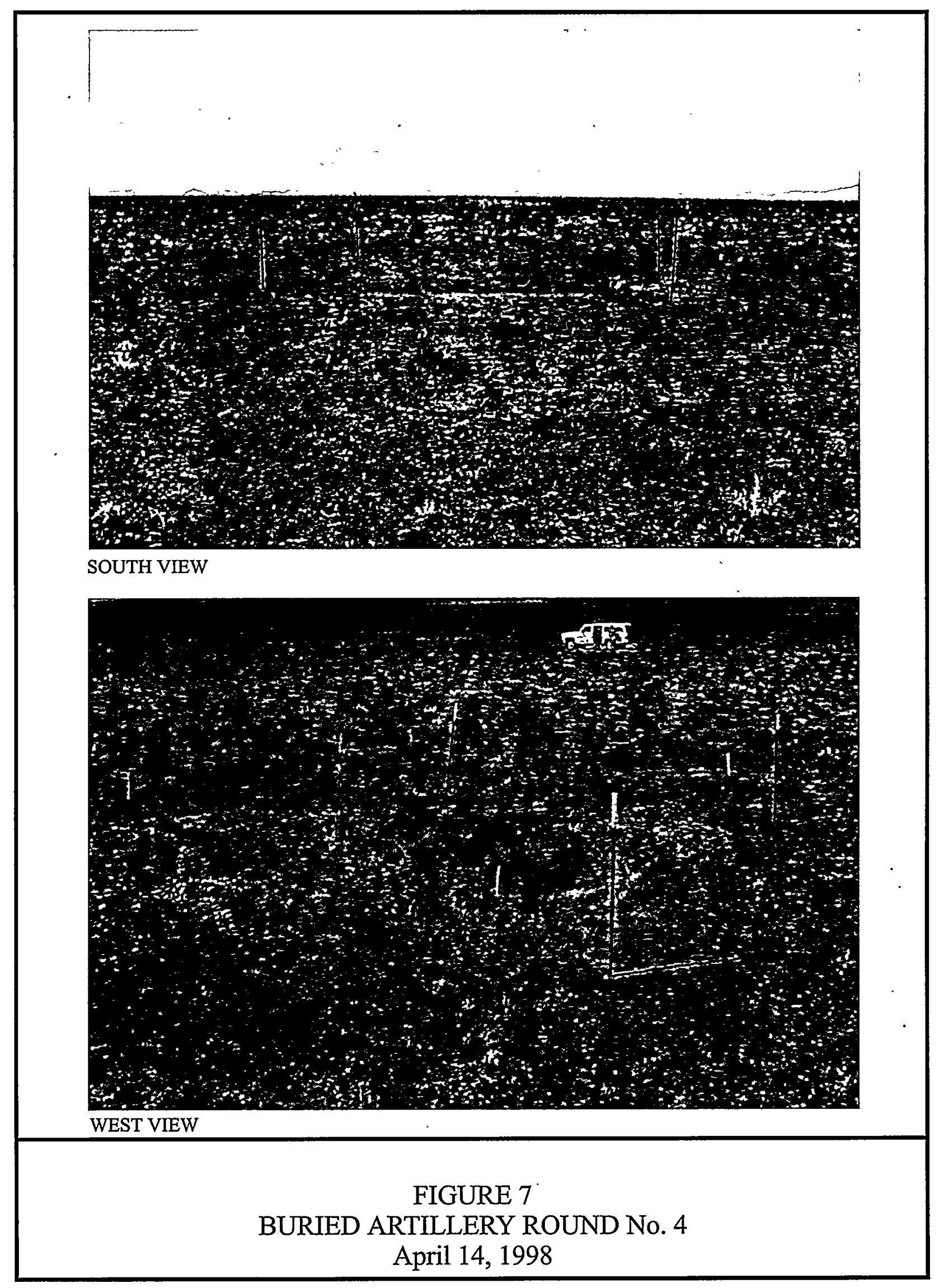


Based on process knowledge, the round was placed into a 6-m (20-ft) excavation along with 5.4 . $\mathrm{kg}(12 \mathrm{lb})$ of $\mathrm{C}-4$ explosive and two steel witness bars. The excavation was backfilled and the C4 was detonated with detacord. The detacord created a pathway which allowed DU to "burp" up . and contaminate the surface: This indicates that the HE in the round was sympathetically detonated with the $\mathrm{C}-4$. The DU found at the surface was cleaned up by range personnel.

A surficial radiological survey conducted in March 1998 did not reveal any readings above background. The volume of impacted soil below the surface is unknown (IT, 1998b).

\subsubsection{CAS No. TA-52-002-TAML: Depletēd Üranium Impact Site}

This CAS consists of an area of disturbed ground containing metal fragments and DU from a . failed weapons test. Historical documentation and examination of fragments suggest that during the 1960s, a 1.5-m (60-in) diameter weapons test unit incurred parachute failure, impacted, and released DU.

The site was discoyered in July 1991 during routine cleanup of an old impact site. Range personnel discovered a significant quantity of yellow metal believed to be DU. Subsequent actions resulted in the excavation of approximately eight 208-I (55-G) drums of metal fragments and soil. Cleanup was stopped after it was determined that the waste was more extensive than anticipated. The remaining contaminated soil and metal fragments were left in place and covered with clean fill. The area was isolated with a 55 by $50-\mathrm{m}$ ( 180 by $160-\mathrm{ft}$ ) fence and posted as a Radiological Control Area (IT, 1998c).

Sampling was done in 1991 and 1996 to analyze for radiological and nonradiological parameters. The results of these analyses indicate the presence of DU and the metals barium, chromium, and lead above regulatory levels (Rarrick, 1991; Sandia, 1997).

A geophysical survey identified the likely location of buried DU. It appears to be fragmented and ranges from $0.4 \mathrm{~m}(1.3 \mathrm{ft})$ to $1.3 \mathrm{~m}$ ( $4.4 \mathrm{ft})$ below ground surface (SAIC, 1998). A radiological survey in January 1998 revealed radiation levels up to 10 times background (IT, 1998c).

\subsubsection{CAS No. TA-55-007-09SE: Buried Artillery Round No. 3}

This CAS is believed to be the impact site of a failed DU artillery round test package. Reliable information is not available as to the date of the test or the existence of the round. However, a geophysical survey conducted in early 1998 concluded that it is plausible the round is present (SAIC, 1998). Radiological surveys conducted in March 1998 detected no radiation levels above background (IT, 1998d). 


\subsubsection{CAS No. TA-55-006-09SE: Buried Artillery Round No. 4}

This CAS is believed to be the impact site of a failed DU artillery round test package. Reliable information is not available as to the date of the test or the existence of the round. However, data from a geophysical survey conducted in early $1998 \mathrm{can}$ be interpreted to identify the artillery round (SAIC, 1998). Radiological surveys conducted in February and March 1998 did not detect radiation levels above background (IT, 1998e).

\subsection{CLOSURE STANDARDS}

The clean closure standards proposed to be used in this SAFER Plan were established for the Streamlined Approach for Environmental Restoration Plan for Corrective Action Unit 430, Buried Depleted Uranium Artillery Round No. 1, Tonopah Test Range (DOE, 1996a). The closure standards established in that plan for Toxicity Characteristic Leaching Procedure (TCLP) metals and semivolatile organic compounds are cited in Title 40 CFR §261.24, Table 1. The closure standards for Nitroaromatics and Nitroamines are from the proposed RCRA Subpart S values found in the Federal Register 55 FR 30796.

The DU closure standard selected for the project was obtained from the Five Points Landfill radiological risk assessment (DOE, 1996b). The Five: Points Landfill radiological risk . assessment analyzed the radiation exposure pathways necessary for a site resident to receive a 100 millirem (mrem)/year dose. This information was then back calculated to determine the DU soil concentration needed to result in a $100 \mathrm{mrem} / \mathrm{year}$ dose.

The proposed closure standards, analytical methods, and standard source for each $\mathrm{COC}$ is found in Table 1. The closure standards established in Table 1 will be used for each CAS. 


\section{TABLE 1 - SUSPECTED CONSTTTUENTS OF CONCERN AND CLOSURE STANDARDS}

\begin{tabular}{|c|c|c|c|c|}
\hline GROUP & INDI!VIDUAL CONSTTTUENTS & METHOD* & $\begin{array}{c}\text { CLOSURE } \\
\text { STANDARD } \\
\text { (ppm) }^{\mathrm{b}}\end{array}$ & $\begin{array}{l}\text { SOURCE OF } \\
\text { STANDARD }\end{array}$ \\
\hline TCLP Metals ${ }^{e}$ & $\begin{array}{l}\text { Arsenic } \\
\text { Barium } \\
\text { Cadmium } \\
\text { Chromium } \\
\text { Lead } \\
\text { Mercury } \\
\text { Selenium } \\
\text { Silver }\end{array}$ & $\begin{array}{l}1311 / 6010 \mathrm{~A} \\
1311 / 6010 \mathrm{~A} \\
1311 / 6010 \mathrm{~A} \\
1311 / 6010 \mathrm{~A} \\
1311 / 6010 \mathrm{~A} \\
1311 / 7470^{\circ} \\
1311 / 6010 \mathrm{~A} \\
1311 / 6010 \mathrm{~A}\end{array}$ & $\begin{array}{c}5 \\
100 \\
1 \\
5 \\
5 \\
0.2 \\
1 \\
5\end{array}$ & $\begin{array}{l}\text { TCLP } \\
\text { TCLP } \\
\text { TCLP } \\
\text { TCLP } \\
\text { TCLP } \\
\text { TCLP } \\
\text { TCLP } \\
\text { TCLP }\end{array}$ \\
\hline $\begin{array}{c}\text { TCLP } \\
\text { Semivolatile } \\
\text { Organics }\end{array}$ & $\begin{array}{l}\text { Nitrobenzene } \\
\text { 2,4-Dinitratoluene }\end{array}$ & $\begin{array}{l}1311 / 8270 \\
1311 / 8270\end{array}$ & $\begin{array}{c}2 \\
0.13\end{array}$ & $\begin{array}{l}\text { TCLP } \\
\text { TCLP }\end{array}$ \\
\hline $\begin{array}{l}\text { Nitroaromatics \& } \\
\text { Nitroamines }\end{array}$ & $\begin{array}{l}\text { Octahydro-1,3,5,7-tetranitro-1,3,5,7- } \\
\text { tetrazocine } \\
\text { Hexahydro-1,3,5-trinitro-1,3,5- } \\
\text { trianzine } \\
\text { 1,3,5-Trinitrobenzene } \\
\text { 1,3-Dinitrobenzene } \\
\text { Methyl-2,4,6-trinitrophenylnitramine . } \\
\text { 2,4,6-Trinitrotoluene } \\
\text { 4-Amino-2,6-dinitrotoluene } \\
\text { 2-Amino-4,6-dinitrotoluene } \\
\text { 2,6-Dinitrotoluene } \\
\text { 2-Nitrotoluene } \\
\text { 3-Nitrotoluene } \\
\text { 4-Nitrotoluene } \\
\text { 2,4-Dinitrotoluene } \\
\text { Nitrobenzene }\end{array}$ & $\begin{array}{l}8330 \\
8330 \\
8330 \\
8330 \\
8330 \\
8330 \\
8330 \\
8330 \\
8330 \\
8330 \\
8330 \\
8330 \\
8330 \\
8330\end{array}$ & $\begin{array}{c}4000 \\
63.6 \\
4 \\
8 \\
800 \\
233.3 \\
1.029^{r} \\
1.029^{r} \\
80 \\
800^{z} \\
800 \\
800 \\
0.13^{c} \\
2^{c}\end{array}$ & $\begin{array}{c}\text { Subpart Se } \\
\text { Subpart S } \\
\text { Subpart S } \\
\text { Subpart S } \\
\text { Subpart S } \\
\text { Subpart S } \\
\text { Subpart S } \\
\text { Subpart S } \\
\text { Subpart S } \\
\text { Subpart S } \\
\text { Subpart S } \\
\text { Subpart S } \\
\text { TCLP } \\
\text { TCLP }\end{array}$ \\
\hline Isotopic Uranium & Uranium $238,239,240$ & L-E10.605.PL & $500 \mathrm{pCi} / \mathrm{g}^{\mathrm{i}}$ & DOE Order 5400.5 \\
\hline
\end{tabular}

'From SW-846 Update III (EPA, 1997)

'Parts per million

Title 40 CFR §261.24, Table 1 .

dMethod for Mercury

'All RCRA Subpart S values were calculated by Art Gravenstein - State of Nevada. Subpart $S$ is a proposed section of 40 CFR $\$ 264$ (DOE, 1996a)

Use value for dinitrotoluene mixture per Art Gravenstein - State of Nevada (DOE 1996a)

gValue is same as that calculated for 3-Nitrotoluene and 4-Nitrotoluene

hBechtel Nevada Intemal Procedure

'Picocuries per gram

TCLP - Toxicity Characteristic Leaching Procedure

RCRA - Resource Conservation and Recovery Act

CFR - Code of Federal Regulations 


\subsection{FIELD ACTIVITIES}

This section provides the framework and rationale for characterization, neutralization, removal, closure verification, site restoration, and waste disposal. The SAFER process is discussed in detail in the following subsections.

Before field activities begin, the following activities will have been completed:

- Endangered species investigation

- Preparation of National Environmental Policy Act (NEPA) documentation

- Preparation of a Health \& Safety Plan (HASP) and Radiological Work Permit (RWP)

- Cultural Resource Survey. Because of the potential to harm cultural resources, off-road driving in areas surrounding the sites is not allowed.

A hazard assessment and HASP will be prepared for this project. Work activities and required personal protective equipment will be dictated by the approved HASP and the RWP. All site workers will be Radiological Worker II-certified and OSHA 40-Hour Hazardous Waste Site Worker-trained (in compliance with 29CFR 1910.120). Only properly trained/certified personnel will operate equipment and handle explosives.

For the CASs containing buried artillery rounds, field activities will include:

- Excavating the soil above the magnetic anomaly.

- Evaluating the magnetic anomaly.

- Inerting the round using HE (if necessary).

- Excavating and stockpile impacted soil and debris.

- $\quad$ Collecting verification soil samples.

- Backfilling excavations with clean fill material.

- Disposing of impacted soil and debris.

For CAS No. TA-52-002-TAML (DU Impact Site), the impacted surface soil and debris will be removed prior to continuing as described above. 


\subsection{CHARACTERIZATION}

Characterization activities will be necessary to determine if an artillery round is, in fact, present and if it requires destruction. Activities will begin by excavating the soil above the potential sites using a backhoe. Excavation will be conducted under the direction of Sandia National Laboratories Explosive Ordnance Disposal (SNL EOD) personnel. Soil will be excavated in lifts up to $0.3 \mathrm{~m}(1 \mathrm{ft})$ to a maximum depth of $3 \mathrm{~m}(10 \mathrm{ft})$. This depth is based on the maximum reasonable depth the backhoe can reach. Also, it is unlikely that the artillery would penetrate beyond this depth. For safety purposes, any excavations greater than $1.5 \mathrm{~m}(5 \mathrm{ft})$ will be benched. Prior to the excavation of each-lift, the area will be surveyed for ordnance/magnetic anomalies and radiological contamination. Excavations will be directed toward the strongest magnetic anomaly. Any radiologically contaminated soil will be placed on plastic sheeting and covered with plastic sheeting.

Excavation will continue in this manner until the magnetic anomaly is within $0.3 \mathrm{~m}(1 \mathrm{ft})$ of the excavated surface or until SNL EOD personnel indicate that it is unsafe to continue with the backhoe. At this point, excavation activities will be done by SNL EOD personnel using only hand tools: When the anomaly is exposed, it will be inspected and identified by SNL EOD personnel. Destruction activities, if necessary, will be done by SNL EOD personnel. After the explosive charges are placed on the projectile, the excavation will be backfilled in $0.3 \mathrm{~m}$ ( $1 \mathrm{ft}$ ) lifts. Each lift will be soaked with water to provide sufficient tamp for the charge. This process will be repeated until the excavation is backfilled. After destruction, remediation activities will continue as described in Section 3.3. .

\subsection{CONSTITUENTS OF POTENTIAL CONCERN}

All of the CAS are similar in nature and are expected to have the same COCs. The primary source of the COCs are the artillery rounds. Based on process knowledge, the expected COCs include DU, lead, chromium, mercury, nitrobenzene, and nitroaromatics and nitroamines (associated with the HE). Table 1 lists all of the potential COCs along with the proposed closur: standards.

\subsection{REMEDIATION}

Remedial activities associated with this project will be completed in two phases. Surface soil remediation (unique to only one of the CASs) and subsurface soil remediation (for the majority of the CASs). If the artillery rounds associated with CAU 495 (the unconfirmed JTA sites) are not located during the characterization process, then remediation will not be necessary. The two phases are discussed in detail in the following sections. 


\subsubsection{Surface Soil Remediation}

The surface soil at the majority of the CASs was not impacted by artillery firing exercises. The rounds, while containing $\mathrm{HE}$, did not detonate or break apart on impact. The one exception was - for CAS No. TA-52-002-TAML (CAU 461). The waste for this CAS is associated with a 1960's weapons air drop. The airdrop weapons development test unit's parachute failed and impacted approximately $610 \mathrm{~m}(2,000 \mathrm{ft})$ south east of the intended target. The weapon broke apart upon impact releasing DU over an estimated 55 by $50 \mathrm{~m}$ (180 by $160 \mathrm{ft})$ area (IT, 1998c):

The site was discovered in July 1991 during routine cleanup of an old impact site. Range personnel discovered a significant quantity of yellow metal believed to be DU. Subsequent actions resulted in the excavation of approximately eight 208-L (55-G) drums of metal fragments and soil. Soil was excavated down to a depth of $0.25 \mathrm{~m}$ (10 in). Excavation was halted when it was determined that the waste was more extensive than anticipated.

Based upon the extensive surface survey during the February 1998 preassessment field investigation the following information is considered likely: The only COCs are DU and the metals barium, chromium, and lead. The majority of the DU is located on the surface and has been mapped. Subsurface activities will probably be confined to the upper $0.61 \mathrm{~m}(2 \mathrm{ft})$ of soil:

Based upon initial review of the preassessment data, after clearance has been obtained from EOD personnel, construction personnel using a front end loader will scrape the surface (imaximum depth $5 \mathrm{~cm}$ [ 2 in]) picking up.DU metal, yellow cake, and potentially impacted soil. The front end loader will place the material into piles. The piles will be loaded onto a conveyor and fed directly into a 15.3 cubic meters $\left(\mathrm{m}^{3}\right)$ (20 cubic yards [yd $\left.\left.\mathrm{d}^{3}\right]\right)$ burrito sack already installed in side loading trucks. It is estimated that a total of $145 \mathrm{~m}^{3}\left(190 \mathrm{yd}^{3}\right)$ of impacted soil will be generated, therefore at least 10 truck loads of material will be generated. After the original $5 \mathrm{~cm}$ ( 2 in) of material has been excavated from the site, Radiological Control Technicians (RCTs) will perform a detailed radiological survey across the site to locate any potential hot spots. EOD personnel will then evaluate the hot spots prior to excavation. Any remaining hot spots will be excavated using a backhoe and placed into a B-25 box. After all surficial hot spots have been excavated and checked, EOD personnel will return to the site to perform a detailed evaluation of the preassessment magnetic anomalies. This will identify the subsurface areas to be excavated.

Eight waste characterization samples of the surface soil will be collected as part of the initial survey prior to surface cleanup activities. All analytical samples will have a two week laboratory turn-around and will be analyzed for the parameters in-Table 1 . After the waste has been characterized a waste profile sheet will be created and submitted for approval to the DOE . Radioactive Waste Acceptance Program (RWAP). Upon RWAP approval, surface cleanup activities will begin and the estimated 10 truck loads will be transported to the Area 3 Low-Level Waste (LLW) facility at the Nevada Test Site (NTS) for proper disposal. 


\subsubsection{Subsurface Soil Remediation}

In the event that DU artillery rounds are located during the characterization phase of the investigation, impacted soil will be generated during the demolition of the DU round. It is expected based upon the detonation procedure that only the soil in the immediate vicinity ( $1 \mathrm{~m} \mathrm{[3}$ $\mathrm{ft}$ ] radius) of the DU round will be impacted.

Re-entry into the excavation after demolition will be done using a backhoe. SNL EOD personnel will direct the excavation activity and will examine the DU round to determine if it has been demilitarized. Upon authorization to proceed by SNL EOD personnel and after a surficial radiological survey has been completed, excavation will begin. RCTs will perform instrument surveys of each backhoe bucket. The RCT survey will be the primary method of segregating the soil removed from the excavation. The key assumption is that subsurface waste will be confined in the area impacted by DU material. Therefore, upon determination that soil within the excavation has reached background radiological levels (using radiological instrumentation), soil removal activities will be halted. Verification samples of the soil for chemical analysis will be collected. The excavation will be barricaded with barbed wire and posted with appropriate warning signs.

Due to the limited volume of soil expected to be generated (approximately $1.5 \mathrm{~m}^{3}$ [2 $\left.\mathrm{yd}^{3}\right]$ ), all potentially impacted soil will be placed in a B-25 box. Excavated soil that is not suspected of containing radionuclides above the action level will bes stockpiled on-site with plastic and covered. Waste characterization samples will be collected from the B-25 box and soil pile. All analytical samples will have a two week turn-around.

If verification sampling indicates that COCs are still present above the closure criteria, additional soil will be excavated and placed into the B-25 box. Additional verification samples will be collected from the impacted area and sent to an off-site analytical laboratory for chemical analysis (two week turn-around). After verification samples indicate clean closure criteria have been reached, the excavation will be backfilled using clean fill and/or the stockpiled soil (if analysis indicates that it is clean). The excavation will be backfilled in approximately $0.3-\mathrm{m}$ (1ft) lifts and compacted to an 80-percent performance standard.

After the B-25 box waste has been characterized a waste profile sheet will be created and submitted for DOE RWAP waste stream approval. Upon RWAP approval, the B-25 box will be transported to the Area 3 LLW facility at the NTS for proper disposal.

The only potential change from the above plan is the subsurface waste associated with CAS No. TA-52-002-TAML. Since the weapon is no longer intact and preliminary geophysical results indicate that all debris is located near the surface (upper $0.62 \mathrm{~m}$ [2 ft]), SNL EOD personnel will examine subsurface debris so that all components of the weapon have been demilitarized. The remainder of the operation will be as described above. 


\subsection{VERIFICATION SAMPLING}

In order to assess the completeness of the remediation activities, soil samples will be collected to confirm that all impacted materials exceeding the established cleanup criteria have been removed. The site-specific COCs (Table 1) consist of DU, metals, semi-volatile organic compounds (SVOCs), and nitroaromatics and nitroamines. The number, location, and chemical analysis method used for the verification samples is provided in Section 3.4.1.

In addition to determination of clean closure at established remediation sites, Section 3.4 .2 provides the criteria for closing a CAS in the event ordnance or impacted material are not found.

\subsubsection{Sampling}

Verification sampling will be conducted in two separate phases. Surface verification sampling will be done at CAS No. TA-52-002-TAML and at the other CASs if detonation of a DU round is conducted. Prior to excavation activities after detonation, the area will be surveyed by RCTs for potential surface contamination. Any impacted surface material will be stockpiled along with other impacted material and disposed. No verification samples are anticipated as it is expected that all impacted soil will be located within the area to be excavated after detonation. However, if surface contamination extends outside of the re-excavation zone, verification samples will be collected. Subsurface verification sampling will only be done at the CASs where DU ordnance was found. No verification samples will be collected from CASs that do not contain DU ordnance. Analytical requirements are found in Table 2 .

\subsubsection{Surface Verification Sampling}

Surface soil verification samples will be taken at CAS No. TA-52-002-TAML. The site is approximately 55 by $50-\mathrm{m}$ ( 180 by $160-\mathrm{ft}$ ) and has significant quantities of DU and the degradation product "yellow cake" spread across the site. The closure methodology calls for removal of the top $5 \mathrm{~cm}$ ( 2 in) of material from across the entire site. A radiologic survey will then be done to identify "hot spots" which will be excavated using a backhoe. The verification sampling activity will consist of two separate approaches. Eight biased verification sample locations will be selected prior to the start of closure work. These eight locations will be photographed, surveyed, and staked. Each location will be selected based upon visual and instrument analysis, with the eight most impacted locations being selected. After the surface cleanup is completed, samples will be collected from these locations and analyzed for TCLP metals, TCLP SVOCs, nitroaromatics and nitroamines, and isotopic uranium.

The remainder of the site will be sampled at random. The entire site will be divided into $3 \mathrm{~m}$ (10 $\mathrm{ft}$ ) by $3 \mathrm{~m}(10 \mathrm{ft}$ ) grids. Sixteen sample locations (approximately five percent of the grids) will be randomly selected using a random number generator. Each random soil sample will be 
TABLE 2 - CLOSURE VERIFICATION ANALYTICAL REQUIREMENTS

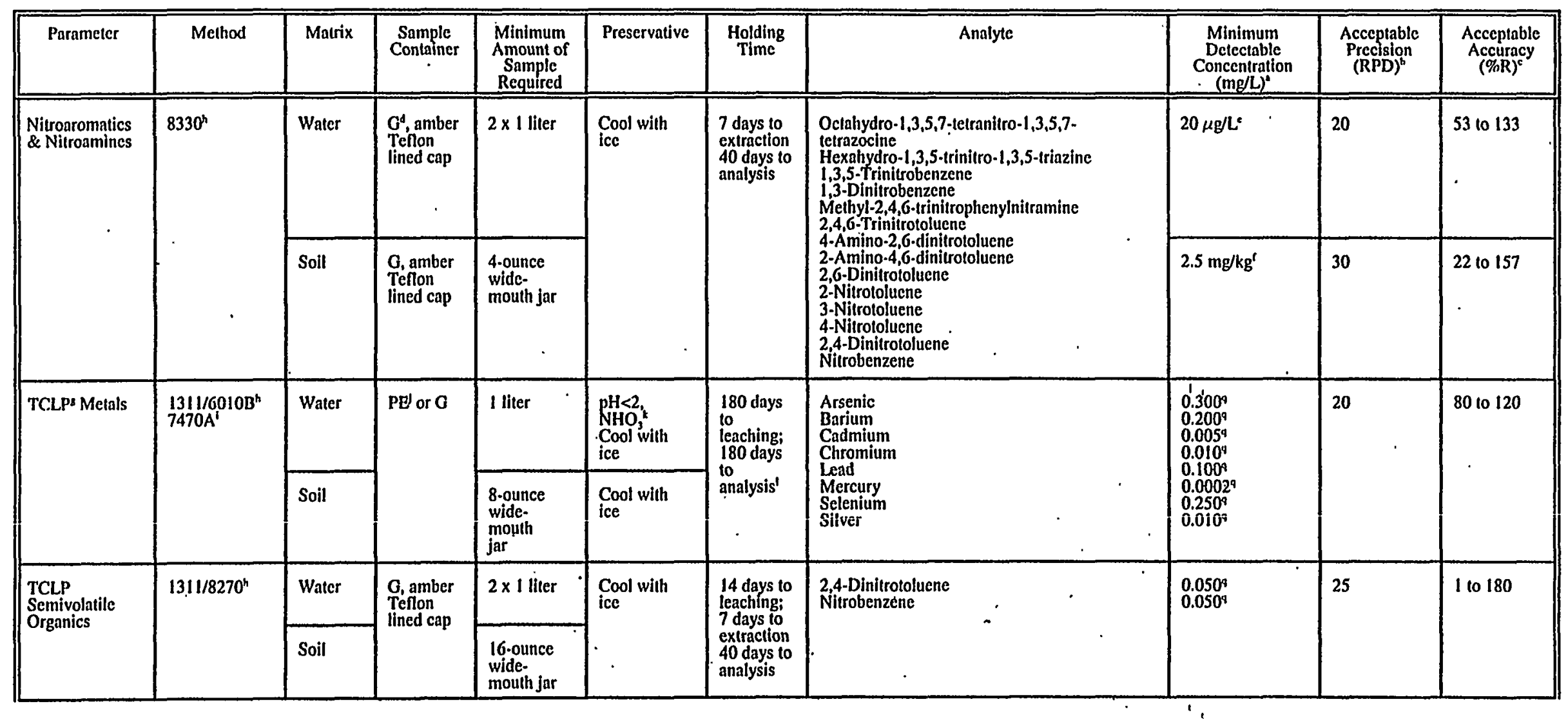


TABLE 2 - CLOSURE VERIFICATION ANALYTICAL REQUIREMENTS (CONTINUED)

\begin{tabular}{|c|c|c|c|c|c|c|c|c|c|c|}
\hline Parameter & $\begin{array}{r}\text { Melhod } \\
: \\
:\end{array}$ & \begin{tabular}{c} 
Matrix \\
\hdashline \\
\hdashline
\end{tabular} & 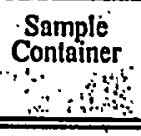 & $\begin{array}{l}\text { Minimum } \\
\text { Amount of } \\
\text { Sample } \\
\text { Required }\end{array}$ & Preservativo & \begin{tabular}{l} 
Holding \\
Time \\
\hdashline \\
\hdashline
\end{tabular} & $\because \quad \because \because \ddots \begin{array}{l}\text { Analyte } \\
\because\end{array}$ & 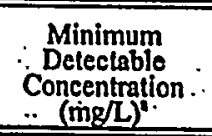 & $\begin{array}{c}\text { Acceptable } \\
\text { Precision } \\
\text { (RPD) }\end{array}$ & $\begin{array}{c}\text { Acceptable } \\
\text { Accuracy } \\
\text { (\%R) }\end{array}$ \\
\hline \multirow[t]{2}{*}{$\begin{array}{l}\text { Isotopic } \\
\text { Uranium }\end{array}$} & L-E10.605.PL & Water & \multirow{2}{*}{ 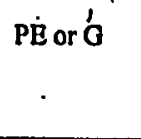 } & 1 liţer & None & \multirow[t]{2}{*}{6 months } & \multirow[t]{2}{*}{$N A^{n}$} & $20 \mathrm{pCi} / \mathrm{L}^{\circ}$ & \multirow[t]{2}{*}{ \pm 20} & \multirow{2}{*}{80 to 120} \\
\hline & L-E10.605.PL & Soil & & 500 grams & None & & & $1.0 \mathrm{pCi} / \mathrm{g}^{\mathrm{ps}}$ & & \\
\hline
\end{tabular}

'Milligrams per liter

Relative percent difference

Percent recovery

${ }^{\circ}$ Glass

"Micrograms pèr liter

Milligrams per kilogram

Toxicity Charncteristic Leaching Procedurc

hEPA Test Mellods for Evaluating Solid Waste, 3rd Edition, Part 1-4, SW-846, 1986

'Method for mercury analysis

Polyethylene

Nitric acid

Except mercury: 28 days to leaching, 28 days to analysis

mechtel Nevada Intemal Procedure

"Not applicable

- Picocuries per liter

picocuries per gram

TTable 6-3, Nevada Environmental Restoration Project, Industrial Sites, QAPP, NTS, Rev. 1, DOE, 1996

'Table 6-4, Nevada Environmental Restoration Project, Industrial Sites, QAPP, NTS, Rev. 1, DOR, 1996 
collected from the center of the grid and analyzed for TCLP metals, TCLP SVOCs, nitroaromatics and nitroamines, and isotopic uranium. A total of 32 samples will be collected including two duplicates, two equipment blanks, two matrix spikes, and two matrix spike duplicates.

\subsubsection{Subsurface Verification Sampling}

Subsurface verification sampling will only be conducted at CASs where DU ordnance was found. Sample locations will be determined by dividing the excavation into four quadrants of approximately equal size and then dividing each of the quadrants into fourths. The intersection in each quadrant will be the designated sample location giving a total of five samples (four sides and bottom of each excavation). Actual sampling locations will be documented in the field. Assuming all sites will be sampled, a total of 75 samples will be collected including five duplicates, five equipment blanks, five matrix spikes, and five matrix spike duplicates.

A potential change in the subsurface verification sampling method for CAS No. TA-52-002TAML will be based on the size of the excavations. Since the weapon is no longer intact, subsurface excavations in some areas may only be "pot holes". In such cases, sampling grids will not be required. Instead samples will be collected from the bottom of these excavations.

Due to confined space concerns and excavation safety issues, samples will be collected from the center of the backhoe bucket. Shallow excavations, sich as the pot holes described above, may be sampled using hand trowels. Pot holes are typically 0.6 by 0.6 by $1.2 \mathrm{~m}$ ( 2 by 2 by $4 \mathrm{ft}$ ). Each excavation requiring clean closure verification will be analyzed for TCLP metals, TCLP SVOCs, nitroaromatics and nitroamines, and isotopic uranium.

\subsubsection{Unconfirmed CAS Closure}

CAU 495 - Unconfirmed JTA Sites consist of two CASs. The exact locations of these artillery impact areas are uncertain. Based upon extensive background research, a possible impact location has been identified for each CAS. However, based upon the huge area in which the DU rounds could impact as well as the presence of large quantities of inert warmer rounds, DU rounds may not be found at the identified location.

A determination must be made to identify whether or not the site contains a DU.round or a warmer round. The only method for determining this is to excavate each location as described in Section 3.1. If it is determined that the site contains only a warmer round, work will stop and DOE and NDEP will be notified. The warmer round will be removed and disposed. If a round is not discovered after excavating to a depth of $3 \mathrm{~m}$ (10 ft), DOE and NDEP will be notified. At that time a decision will be made whether additional excavation is warranted. 


\subsection{CLOSURE}

The activities required for closure are as follows:

\section{CAÙ 461:}

CAS No. TTR-001

- Excavate and identify artillery shell.

- Destroy by detonation (if necessary) the artillery shell.

- Re-excavate artillery shell and impacted soil.

- Collect verification samples.

- Backfill excavation.

- Transport soil and debris to an NTS LLW repository after receiving RWAP approval.

CAS No. TA-52-003-0960

- Excavate artillery shell debris and impacted soil.

- Collect verification samples.

- Backfill excavation.

- Transport.soil and debris to an NTS LLW repository after receiving RWAP approval.

CAS No. TA-52-002-TAML

- Excavate surface debris and impacted soil to a depth of $5 \mathrm{~cm}$ (2 in) and over-excavate identified "hot spots".

- Collect biased and random verification samples.

Excavate subsurface debris and impacted soil.

- Collect verification samples.

- Backfill excavations.

- Transport soil and debris to an NTS LLW repository after receiving RWAP approval. 


\section{CAU 495:}

CAS No. TA-55-006-09SE and CAS No. TA-55-007-09SE

- Excavate and identify artillery shell.

- Destroy by detonation (if necessary) the artillery shell.

- Re-excavate artillery shell and impacted soil.

- $\quad$ Collect verification samples.

- Backfill excavation.

- Transport soil and debris to an NTS LLW repository after receiving RWAP approval.

If an artillery round is identified as a warmer round, then DOE and NDEP will be notified. The warmer round will be removed so that surveys for other magnetic anomalies can be done.

\section{6 - DURATION}

The closure field activities are scheduled to begin three weeks after approval of this plan by NDEP and are outlined as follows:

- Submit Final SAFER Work Plan tọ DOE and NDEP.

- Prepare for field work (assign work crew, obtain heavy equipment, logistical support, necessary permits).

- Begin field closure activities. Work is anticipated to take six weeks.

- Submit Draft SAFER Closure Report to DOE.

The schedule will require modification if conditions exist that are outside the assumptions on which the schedule was developed. Flexibility has been placed in the project schedule to account for minor difficulties (weather, equipment breakdowns, personnel availability, etc.) DOE will keep the NDEP apprised of any conndition that may impact the project schedule. 


\subsection{REPORTS AND RECORDS AVAILABILITY}

A daily report will be prepared once field activities have started. The report summarizes the daily project accomplishments and any problems that may have been experienced. The report will be provided to the DOE Task Manager for submittal to the NDEP.

Upon completion of closure activities, a SAFER Closure Report will be prepared and will include the following:

- Introduction (Purpose and Scope)

- Characterization and Closure Activities (Description of field activities)

- Waste Disposition (RWAP documentation)

- Conclusions

The final closure report will be submitted to DOE and NDEP for review and approval. This SAFER work plan and the subsequent closure report will be available in the DOE Public Reading Room located in Las Vegas and Carson City, Nevada, or by contacting the DOE Project Manager. The NDEP maintains the official administrative record for all activities conducted under the auspices of the FFACO (NDEP et al, 1996). 


\subsection{WASTE MANAGEMENT}

Upon receipt of waste characterization samples and RWAP approval, the impacted soil, debris, and compactable trash will be shipped directly to an approved LLW repository at the NTS. All DOE and Department of Transportation (DOT) regulations pertinent to the transport of LLW will be followed.

\subsection{WASTE MINIMIZATION}

Waste generation will be minimized by limiting the number of people in the work area. In addition, work in the exclusion zone will be planned in advance to limit the number of times personnel will be required to dress out.

\subsection{POTENTIAL WASTE STREAMS}

Waste generated from characterization and closure activities will consist of radiologically impacted soil and debris, DU, hazardous soil and debris, personal protective equipment (PPE); and sanitary trash. There is the potential for mixed waste from the hazardous components in the $\mathrm{HE}$ residue. However, it is likely that the levels will be below Land Disposal Restrictions and can be disposed of as LLW. 


\subsection{REFERENCES}

Code of Federal Regulations, 1996, Title 40 Part 261.24, Table 1, Washington, D. C:

DOE, see U.S. Department of Energy

EPA, see U.S. Environmental Protection Agency

NDEP, see Nevada Division of Environmentā Protection

Nevada Division of Environmental Protection, U.S. Department of Energy; and U.S. Department of Defense, April 1996, Federal Facilities Agreement and Consent Order (FFACO) of 1996.

IT, 1998, Field Activity Daily Log, 01/21/98, Las Vegas, Nevada.

IT, 1998a, Project Files for CAU 461. CAS TTR-001, Las Vegas, Nevada.

IT, 1998b, Project Files for CAU 461, CAS TA-52-003-0960, Las Vegas, Nevada.

IT, 1998c, Project Files for CAU 461. CAS TA-52-002-TAML, Las Vegas, Nevada.

IT, 1998d, Project Files for CAU 495, CAS TA-55-006-09SE, Las Vegas, Nevada.

IT, 1998e, Project Files for CAU 495, CAS TA-55-007-09SE, Las Vegas, Nevada.

Rarrick, Harold, Sandia National Laboratories, 1991, Letter from H. Rarrick to G. West regarding the sample results collected from the DU Impact Site, 13 September, Albuquerque, New Mexico.

Rodriguez, Cheryl, IT Corporation, 1997, E-Mail to M. Hagenow and M. England regarding GPS Coordinates for the IT monuments at TTR, 24 September, Las Vegas, Nevada.

Sandia National Laboratories, 1990, 1989 Environmental Monitoring Report, Tonopah Test Range, Tonopah. Nevada, Albuquerque, New Mexico.

Sandia National Laboratories, 1997, 1996 Site Environmental Report. Tonopah Test Range, Tonopah, Nevada, Albuquerque, New Mexico.

Science Applications International Corporation, 1998, First Quarter 1998 Surface Geophysical Survey Report. Depleted Uranium Impact Site (CAU 461), 1987 W79 Joint Test Assembly (CAU 461) Sites A and B, and Buried Artillery Rounds (CAU 495) \#3 and \#4, Tonopah Test $\underline{\text { Range, Nevada, Middletown, Pennsylvania. }}$ 
U.S. Department of Energy, 1994, Nevada Environmental Restoration Project. Project Management Plan, Revision 0, Las Vegas, Nevada.

U.S. Department of Energy, 1994a, Tonopah Test Range. Site Priority Ranking Model, Las Vegas, Nevada.

U.S. Department of Energy, 1996a, Draft Streamlined Approach for Environmental Restoration Plan for Corrective Action Unit 430. Buried Depleted Uranium Artillery Round No. 1. Tonoaph Test Range, Las Vegas, Nevada.

U.S. Department of Energy, 1996b, Streamlined Approach for Environmental Restoration Plan, CAU No. 400: Bomblet Pit and Five Points Landfill, Tonopah Test Range, Las Vegas, Nevada.

U.S. Department of Energy, 1996c, Nevada Environmental Restoration Project, Industrial Sites, Quality Assurance Project Plan, Revision 1, Las Vegas, Nevada.

U.S. Environmental Protection Agency, 1997, Test Methods for Evaluating Solid Waste. Physical/Chemical Methods, SW-846. 3rd Edition, Update III, Washington, D.C.

55 FR 30796, Corrective Action for Solid Waste Management Units (SWMUs) at Hazardous Waste Management Facilities, Proposed Rule, Washington, D.C. 


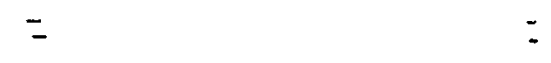

APPENDIX A

PROJECT ORGANIZATION 


\section{PROJECT ORGANIZATION}

The DOE/NV Project Manager or Task Manager will serve as the primary point of contact for all activities conducted for this project. The DOE/NV Project Manager is responsible for seeing that all activities conducted during the project fulfill the obligations of DOE/NV, as described in the FFACO and the NDEP approved work plan. The DOE/NV Project Manager will plan, authorize, and control project work so that activities are completed in accordance with the work plan on schedule and within budget. The DOE/NV Project Manager will be the primary point of contact with the NDEP. The DOE/NV points of contact for this project are as follows:

Project Manager: Janet Appenzeller-Wing

Telephone Number: (702) 295-0461.

Task Manager: Kevin Cabble

Telephone Number: (702) 295-5000

The identification of the project Health and Safety Officer and the Quality Assurance Officer can be found in both the Field Management Plan and the Site-Specific Health and Safety Plan.

However, personnel are subject to change and it is suggested that the Project Manager be contacted for further information. The Task Manager will be identified in the FFACO Biweekly Activity Report prior to the start of field activities. 


\section{APPENDIX B}

\section{NEVADA DIVISION OF ENVIRONMENTAL PROTECTION DOCUMENT REVIEW SHEET}




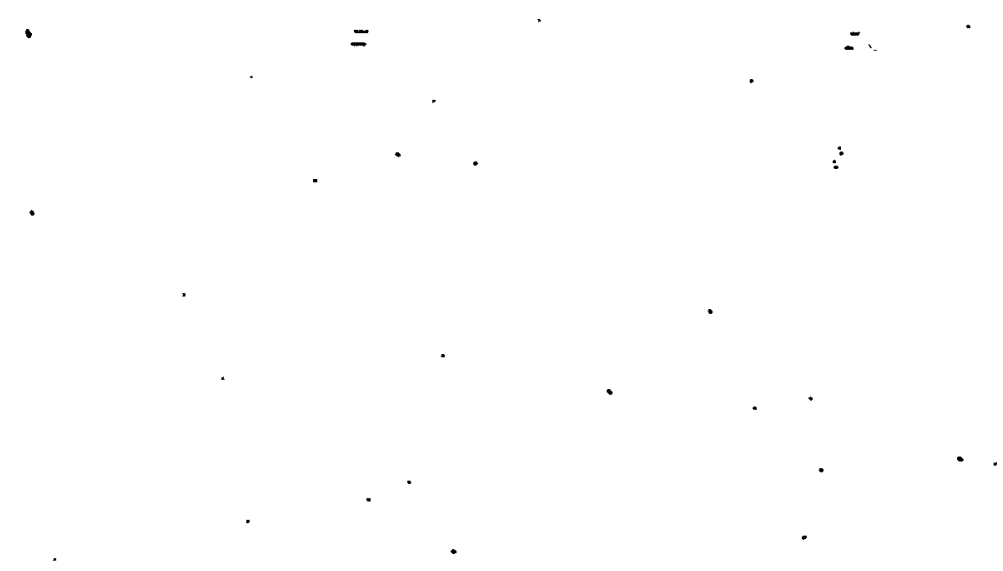

\section{DISTRIBUTION LIST}


Document Title/Number: Draft SAFER Work Plan for CAU 461 JTA Sites and CAU 495 Unconfirmed JTA Sites, Tonopah Test Range, Nevada. DOE/NV/11718--247

Document Date: July 1998

Revision Number: 0

Originator/Organization: Dan Tobiason/Bechtel Nevada Environmental Restoration

Date Comments received: August 24, 1998

Reviewer/Organization: Michael D. McKinnon/Nevada Division of Environmental Protection

\begin{tabular}{||c|c|c|c|c||}
\hline $\begin{array}{c}\text { Comment } \\
\text { Number/ } \\
\text { Location }\end{array}$ & Type & \multicolumn{1}{|c|}{ Comment } & Comment Response \\
\hline \hline a. General & $\mathrm{M}$ & $\begin{array}{l}\text { Since this work will be performed on Tonopah } \\
\text { Test Range (TTR), concurrence (in writing) } \\
\text { from the Air Force and acknowledgement from } \\
\text { DOE/ALOO is required before NDEP can } \\
\text { provide approval on the Final SAFER Work } \\
\text { Plan. }\end{array}$ & $\begin{array}{l}\text { DOE/NV ERD staff will brief US } \\
\text { Air Force and DOE/ALOO } \\
\text { personnel and get their concurrence } \\
\text { (in writing). }\end{array}$ \\
\hline b. General & $\mathrm{M}$ & $\begin{array}{l}\text { If this work plan has nọt been presented to the } \\
\text { CAB, that action (in conjunction with the } \\
\text { release of the Final SAFER Work Plan) will be } \\
\text { required before NDEP can provide approval of } \\
\text { the Final SAFER Work Plan. }\end{array}$ & $\begin{array}{l}\text { The briefing agreement between the } \\
\text { poE and CAB refers to closure in } \\
\text { 495 SAFER is a Clean Closure, no } \\
\text { CAB briefing is required. }\end{array}$ \\
\hline
\end{tabular}

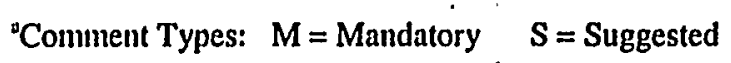




\begin{tabular}{||c|c|c|c|c|}
\hline $\begin{array}{c}\text { Comment } \\
\text { Number/ } \\
\text { Location }\end{array}$ & Type & \multicolumn{1}{|c|}{ Comment } & Comment Response \\
\hline \hline c. General & $\mathrm{M}$ & $\begin{array}{l}\text { As discussed at the August 19, 1998 FFACO } \\
\text { meeting, combining Corrective Action Units } \\
\text { (CAUs) into one plan will only be approved on } \\
\text { rare occasions after a case-by-case review. } \\
\text { This combined SAFER Work Plan, after } \\
\text { incorporating responses to paragraphs a. and b. } \\
\text { above, will be acceptable with the } \\
\text { understanding that all work for both CAUs will } \\
\text { be completed and reported within one final } \\
\text { closure document. }\end{array}$ & $\begin{array}{l}\text { One closure report that includes all } \\
\text { of the CASs from the two CAUs } \\
\text { will be generated. }\end{array}$ \\
\hline
\end{tabular}




\section{DISTRIBUTION LIST}

Paul Liebendorfer

Bureau of Federal Facilities

Division of Environmental Protection

333 W. Nye Larie, Room 13B

Carson City, NV 89706-0866

Office Administrator

Bureau of Federal Facilities

Division of Environmental Protection

555E. Washington, Suite 4300

Las Vegas, NV 89101
2 (Controlled)

1 (Controlled)

U.S. Department of Energy, Nevada Operations Office

Environmental Restoration Division

P.O. Box 98518

Las Vegas, NV 89193-8518

\section{J. L. Appenzeller-Wing}

K. J. Cabble

S. Bonnell

1 (Uncontrolled)

1 (Uncontrolled)

1 (Controlled)

Public Reading Room

P.O. Box 98521 , M/S NLV040

1 (Conitrolled)

Las Vegas, NV 89193-8521

Technical Information Resource Center .

1 (Uncontrolled)

P.O. Box 98518, M/S 505

Las Vegas, NV 89193-8518

\section{U.S. Department of Energy,}

Office of Scientific and Technical Information

P.O. Box 62

2 (Uncontrolled) 
Bechtel Nevada

P.O. Box 98521

Las Vegas, NV 89193-8521

Correspondence Control

1 (Uncontrolled)

S. L. Alderson

1 (Uncontrolled)

D. K. Cowser

1 (Uncontrolled)

S. J. Nacht

1 (Uncontrolled)

J. L. Smith

1 (Uncontrolled)

K. A. Quintana

1 (Uncontrolled)

R. S. Remington

1 (Uncontrolled)

IT Corporation

P.O. Box 93838

Las Vegas, NV 89193

K. C. Beach

2 (Uncontrolled) 